IRSH 65 (2020), pp. I 9I-230 doi:I0.1017/So0208590I 9000774

(C) 2020 Internationaal Instituut voor Sociale Geschiedenis

\title{
Women and Gender in the Mines: Challenging Masculinity Through History: An Introduction*
}

\author{
Rossana BaRRAgÁn Romano \\ International Institute of Social History \\ Cruquiusweg 3I, IOI9 AT Amsterdam, The Netherlands
}

E-mail: rba@iisg.nl

\author{
LEDA PAPASTEFANAKI \\ Department of History and Archaeology School of Philosophy \\ University of Ioannina \\ Campus University Ioannina 45 I I0, Greece \\ Institute for Mediterranean Studies - FORTH \\ I30 N. Foka str., Rethymno 74100, Greece \\ E-mail: lpapast@uoi.gr
}

\begin{abstract}
The role of women as mineworkers and as household workers has been erased. Here, we challenge the masculinity associated with the mines, taking a longer-term and a global labour history perspective. We foreground the importance of women as mineworkers in different parts of the world since the early modern period and analyse the changes introduced in coal mining in the nineteenth and early twentieth century, the masculinization and mechanization, and the growing importance of
\end{abstract}

\footnotetext{
* This thematic issue is based on the two sessions on "Women and Gender Relations in the Labour Force: The Case of Mining, I 500-2000" that we organized in the Feminist Labour History Working Group at the Ist European Labour History Network Conference in Turin (I4-I6 December 20I5) and in the Labour Network at the European Social Sciences History Conference in Valencia (30 March to 2 April 2016). The comments of the discussants, Raffaella Sarti in Turin and Karin Hofmeester in Valencia, as well as the comments of all the sessions' participants were precious; we thank them all. We wish to thank, too, Aad Blok, Ad Knotter, Marcel van der Linden, and Filipa Ribeiro da Silva for their comments on a previous versions of the manuscript; Eloisa Betti and Liliosa Azara for some fruitful discussions in Rome and Bologna; Agustín Fleta and Paulo Guimarães for discussions we had in Amsterdam during the 3 rd European Labour History Network Conference; Francesca Sanna for her valuable help on the bibliography for the Italian case; and Miguel Á. Pérez de Perceval Verde, Ángel Pascual Martínez Soto, and José Joaquín García Gómez for their patience. We thank, too, Yannis Gonatidis and Claire Tsakiris, assistant researchers on the project "Mining Landscapes in Greece, Igth-2oth Centuries" of the Institute for Mediterranean Studies - FORTH, for helping us with the bibliography, and Paola Villarroel, who helped us with some of the tables.
} 
women in contemporary artisanal and small-scale mining. The effect of protective laws and the exclusion of women from underground tasks was to restrict women's work more to the household, which played a pivotal role in mining communities but is insufficiently recognized. This process of “de-labourization” of women's work was closely connected with the distinction between productive and unproductive labour. This introductory article therefore centres on the important work carried out in the household by women and children. Finally, we present the three articles in this Special Theme and discuss how each of them is in dialogue with the topics addressed here. Many thanks also to Marie-José Spreeuwenberg for her invaluable engagement.

The historiography of mining has largely ignored mining women, as well as the wives of the miners. ${ }^{\mathrm{I}}$

Mining's tumultuous history evokes images of rootless, brawny and often militant men, whether laboring in sixteenth-century Peru or twenty-first-century South

Africa. $^{2}$

This focus, on large, formally owned and operated, corporate capital mineral extraction processes, ignores how poor people actually live on mineral-rich tracts in the world. Peasant or informal mining and quarrying - digging, washing, sieving, panning and amalgamating - provide livelihood for at least I 3 million people in the global south (ILO, I999). Extracting low volumes of minerals from small and scattered deposits using little capital/technology, and with low labour cost, productivity and returns, is a worldwide phenomenon $[\ldots]^{3}$

The central argument in this Special Theme, and in this Introduction, is that in the history of mining the role of women as mineworkers and women as household workers has been overlooked. As early as I993, Christina Vanja pointed out that the number of women working as miners was being underestimated, while in 2007 Laurie Mercier and Jaclyn Gier emphasized how mining has predominantly been associated with masculinity, and in 2012 Kuntala Lahiri-Dutt called into question the focus on big mining in mining history, which contributed to ignoring the role of women. ${ }^{4}$ This erasure of women from the history of mining can be explained by the focus in the historiography on the implementation since the first decades of the nineteenth century of laws to protect women and children, resulting in a ban on and the exclusion of

I. Christina Vanja, "Mining Women in Early Modern European Society”, in Thomas Max Safley and Leonard N. Rosenband (eds), The Workplace before the Factory: Artisans and Proletarians, I 500-I 800 (Ithaca, NY, and London, I993), pp. I00-I I7, I00.

2. Laurie Mercier and Jaclyn Gier, "Reconsidering Women and Gender in Mining", History Compass, 5:3 (2007), pp. 995-100I, 995.

3. Kuntala Lahiri-Dutt, "'May God Give Us Chaos So That We May Plunder': A Critique of 'Resource Curse' and Conflict Theories", Women in Action, 2 (2006), pp. I 8-28, 22.

4. Vanja, "Mining Women in Early Modern European Society"; Mercier and Gier, "Reconsidering Women and Gender in Mining”; Lahiri-Dutt, “"May God Give Us Chaos”. 
women and children from working in underground mines. This exclusion can also be explained by the dominance of the breadwinner model and an ideology that considered women primarily as mothers and reproducers of the labour force.

Taking a longer-term, global labour history perspective, ${ }^{5}$ it is important to underline the fact that women were as active as miners in the past as they are in the present. The history of women as miners allows us to understand how state and employers' policies contributed to masculinizing work and sites of labour by implementing protective laws. This was a process that ran parallel to what has been labelled the "de-labourization" of women ${ }^{6}$ since the eighteenth century: the development by which women were increasingly excluded from more or less formal wage labour employment by state and employer regulations, based on a male breadwinner ideology and the masculinization of workplaces and work processes. This tendency lasted until the mid-twentieth century, when, in the name of equality, protective laws came to be considered discriminatory against women; they were then increasingly dismantled. The process of masculinization was also concomitant with the development of a social welfare system in European countries, although it did not extend to the rest the world, where an increasing "informal economy" gained ground. The mining sector in the Global South was part of this process and it was women's informal work that extended throughout the mines. On a longer-term global scale, women were evicted from mining for a period of i 50 to 200 years, to reappear in the present era, mainly in the Global South, but in the worst and most precarious conditions.

As a result of the protective laws and the exclusion of women from underground tasks, women's work became increasingly restricted to household work, while their pivotal role in reproduction and care work in mining communities was also insufficiently recognized. This process of "de-labourization" of women's work and the closely connected distinction made between productive and unproductive labour was in accordance with the classical political economy since Adam Smith, where unpaid care work and domestic activities were considered "unproductive" labour and underestimated.?

5. Marcel van der Linden, Workers of the World: Essays Toward a Global Labor History (Leiden and Boston, MA, 2008); Jaclyn J. Gier and Laurie Mercier (eds), Mining Women: Gender in the Development of a Global Industry, I670 to 2005 (New York, 2006); Kuntala Lahiri-Dutt and Martha Macintyre (eds), Women Miners in Developing Countries: Pit Women and Others (Burlington, VT, 2006).

6. Raffaella Sarti, Anna Bellavitis, and Manuela Martini (eds), What is Work? Gender at the Crossroads of Home, Family, and Business from the Early Modern Era to the Present (New York, 2018).

7. On productive, unproductive, and reproductive work, see, among others, Raffaella Sarti, Anna Bellavitis, and Manuela Martini, "Introduction", in idem, What is Work?, pp. I 5-22; Alessandra Pescarolo, "Productive and Reproductive Work: Uses and Abuses of an Old Dichotomy", in Sarti et al., What is Work?, pp. I I4-138; Eileen Boris, "Subsistence and Household Labour", in 
Although opinions and attitudes towards women and mining were unequal in different societies around the globe, ${ }^{8}$ domestic ideology in Europe and North America, originating from eighteenth- and nineteenth-century debates on "women's nature", was adjusted to the particular circumstances of the Industrial Revolution, providing a moral rationale for keeping women out of the mines and at home. A domestic ideology and the male breadwinner ideology concealed the concrete meaning of the gender division of labour for women's work in mining households, as well as the value of women's unpaid labour to the mining industry. ${ }^{9}$

In this Introduction, we will give an overview of the paid and unpaid labour of women in mines and in mining households, referring to cases that illuminate trends or transformations within regions in different national and colonial settings, and within a wide variety of minerals, though without pretending to be exhaustive. We will then introduce the three articles in this Special Theme and explain how each contributes to the main issues addressed here.

\section{WOMEN AS MINEWORKERS}

Mining is a complex process, and although different minerals have their own specificities generally speaking there are different production stages, starting with the extraction of ores in underground pits, or on the surface, going subsequently through different steps of mineral processing, i.e. the extraction of minerals underground or at the surface, and the process to obtain metals from ores through crushing/grinding, separation, dewatering, and drying. Looking closely at this whole production process, women played a more active role than is often thought. It is important to distinguish the various steps in order to analyse the division of labour by age and sex and to understand how laws affected underground mining and surface mining differently.

Karin Hofmeester and Marcel van der Linden (eds), Handbook Global History of Work (Berlin, 2018), pp. 329-344; Eileen Boris, "Reproduction as Production: Thinking with the ILO to Move beyond Dichotomy", Journal of Labor and Society, 22:2 (2019), pp. 283-298.

8. On the different attitudes and beliefs towards women and mining in Africa, Asia, and Latin America, see Jaclyn J. Gier and Laurie Mercier, "Introduction”, in Gier and Mercier, Mining Women, pp. 4-5. For an example of women's exclusion from underground work in Bolivia, see Pascale Absi, "Pourquoi les femmes ne doivent pas entrer dans les mines... Potosi, Bolivie", L'Homme et la société, I 46 (2002), pp. I4I-I 57. The author claims that the workers regarded the mountain as a woman they fertilize with their work, as a female divinity associated with fecundity, and as the Virgin Mary. If a woman entered the mines, the mountain became "jealous" and hid its richness.

9. Gier and Mercier, "Introduction", pp. I-4; Jaclyn J. Gier and Laurie Mercier, "Engendered Bodies and the Masculinization of the Mining Industry: Separate Spheres and the Role of Women in Mining, the Mining Household, and Community, I800-1940", in idem, Mining Women, pp. 89-95. 
This Introduction aims first to foreground the importance of women as mineworkers in different parts of the world, and for the diverse minerals exploited, since the early modern period. Second, we focus on the changes introduced specifically in coal mining during the Industrial Revolution, throughout the nineteenth century, and in the first few decades of the twentieth century. Third, we aim to underline the growing importance of women in contemporary small-scale and artisanal mining, where they make up more than forty per cent of the workforce (compared with around ten per cent in large-scale mining). ${ }^{\mathrm{IO}}$

Women at work between the end of the sixteenth and the end of the eighteenth centuries In the early modern period, all over the world, work in mines was an activity performed by the family: men, women, and children. In Europe, various tasks crucial for the existence of mining communities were undertaken by women in underground mines and above ground. Vanja stated that mining could be a form of household enterprise similar to other crafts in such a way that, until the nineteenth century, teams of husbands and wives could be found working together. ${ }^{\text {II }}$ Frequently, a gender division of labour existed: men were mainly hewers (as in the coal industry), while women would break ores and metals, rinsing, sorting, washing, hauling, and moving ores. Women also used to do various transport-related jobs, such as carrying wood and coal to heat the furnaces or transporting the cold iron. However, women received less pay: in the mid-sixteenth century, women's wages were only half those of men. ${ }^{\text {I2 }}$ In early modern German mining, women were employed above ground in picking, sorting, hammering, and washing the ore. In coal mining, until I892, the miners' wives and children worked as drawers, pulling sledges or tubs to the bottom shaft, and as haulers. ${ }^{13}$ In Britain, family work was also very common until the early nineteenth century, and women worked underground in the coal mines in family teams. ${ }^{14} \mathrm{~A}$ recent study states that forty per cent of

Io. IWIM, International Women in Mining, Women in Mining: Can a Mining Law Unlock the Potential of Women? (2017), p. I7: available at https://issuu.com/adamsmithinternational/docs/ asi__iwim_2017; last accessed 29 May 2019.

I I. Vanja, "Mining Women in Early Modern European Society", pp. I02-I I 5, I03. See also Jason Sampson, "Colliers in Corsets? Uncovering Stark County's Nineteenth-Century Coal Mining Women": available at https://escholarship.org/uc/item/4n46giwo; last accessed 22 November 2019.

I 2. Vanja, "Mining Women in Early Modern European Society", p. I I 3.

I3. Ad Knotter, "Mining", in Hofmeester and van der Linden, Handbook Global History of Work, pp. 237-258, 252-253.

I4. Angela V. John, By the Sweat of Their Brow: Women Workers at Victorian Coal Mines (New York, 1980). 
workers in Scottish mines were female, hauling and bearing coal, work that was a legacy of a system of serfdom. ${ }^{\mathrm{IS}}$

In India, in the Golconda region, diamonds were also worked by the family. In the early seventeenth century, there were c.50,000 men digging pits, while women and children carried away the earth. ${ }^{16}$ In Spanish America, ${ }^{17}$ from the sixteenth to the eighteenth centuries the silver and gold mines doubled or tripled the world's stock of money. ${ }^{18}$ An estimated I 50,000 tons of silver were produced between I 500 and I 800 , representing eighty per cent of the entire global production in this period. ${ }^{19}$ Silver was directly worked by men. However, as Velasco noted, male work was underground, while female work above ground has been largely ignored. ${ }^{20}$ Women were more present as mineworkers in the most important gold regions, such as New Granada (present-day Colombia) and Brazil. In Brazil, the gold rush of the eighteenth century brought slavery to the mines, rivalling the slave-sugar plantations. Although only men were portrayed as explorers, frontier settlers, and mine labourers, ${ }^{21}$ female slaves were painted working on the rivers, ${ }^{22}$ and as negras de Tabuleiro (escrava de ganho) or slave hawkers in Minas Gerais. ${ }^{23}$ In what is today Colombia, gold extraction was mainly in the hands of the mine's gang

I 5. David M. Turner and Daniel Blackie, Disability in the Industrial Revolution (Manchester, 2018).

16. Karin Hofmeester, "Economic Institutions and Shifting Labour Relations in the Indian, Brazilian, and South African Diamond Mines", in idem and Pim de Zwart (eds), Colonialism, Institutional Change and Shifts in Global Labour Relations (Amsterdam, 2018), pp. 67-108, 7I-72.

I7. In Pre-Hispanic America, some exceptional evidence shows the work of women underground in Chuquicamata, in present-day northern Chile, and in the gold mines of the Andes. Valentina Figueroa et al., "Pre-Hispanic Mining Ergology of Northern Chile: An Archaeological Perspective", Chungara, Revista de Antropología Chilena, 45:I (20I3), pp. 6I-8I; Thérèse Bouysse Cassagne, "Les mines d'or des Incas, le Soleil et les cultures du Collasuyu", Bulletin de l'Institut français d'études andines, 46:I (2017), pp. 9-36.

I8. Richard Garner, "Mining Trends in the New World I 500-1 8 10": manuscript at http://www. insidemydesk.com/lapubs/miningtrends.pdf; last accessed 20 August 2019.

19. Arturo Giraldez Rivero, "Born with a Silver Spoon: China, American Silver and Global Markets during the Early Modern Period (Ph.D., University of Amsterdam, I 999), pp. 3 I-32, 40. 20. Dana Velasco Murillo, "Laboring above Ground: Indigenous Women in New Spain's Silver Mining District, Zacatecas, Mexico, 1620-1770", Hispanic American Historical Review, 93:I (2013), pp. 3-32.

2 I. Kathleen Higgins, "Licentious Liberty" in a Brazilian Gold-Mining Region: Slavery, Gender, and Social Control in Eighteenth-Century Sabará, Minas Gerais (University Park, PA, 2007), p. 38 .

22. Junia Furtado, “Mulheres escravas e forras na mineração no Brasil, século XVIII”, paper presented at the ALIHSS, Lima, I-4 October 2019.

23. Liliana Maria Reis, "Mulheres de ouro: As Negras de Tabuleiro nas Minas Gerais do Século XVIII”, Revista do Departamento de História, Belo Horizonte, 8 (1989), pp. 72-85, 75-78. 
overseers (señores de minas y cuadrillas) working with at least five slaves, led by a captain male slave or female slave in the case of female gangs. ${ }^{24}$ Throughout the region of Antioquía and in the Chocó, the presence of women as workers is more evident. In Antioquía, gold was extracted by slave gangs (cuadrillas) and by independent peasant-miners called mazamorreros, comprising free slaves, mulattoes, and Indians. ${ }^{25}$ The mazamorreros accounted for two thirds of the region's gold output in $1786 .{ }^{26}$ They worked the mines with their family, but some of them could have owned slaves. In Cáceres, in 1796, twenty-four mines were worked by slaves, free day workers (jornaleros), and gangs comprising both slaves and free people. The slave population of 244 people was distributed among seven owners (two women), while there were 137 free workers distributed among twenty owners. ${ }^{27}$ In the Chocó region, gold output between 1735 and 1799 accounted for between forty-five and seventy per cent of the total official gold produced in New Granada (Colombia). Here, gold exploitation was an important area of family work, including women and children. There were fewer than two men for every woman among working slaves; three decades later, women comprised more than forty-five per cent of all slaves. Particularly important in the region was the growing number of slaves who purchased their freedom. ${ }^{28}$

From the end of the eighteenth century there were important changes. Christina Vanja describes how Europe's small mines were absorbed into larger, capitalistic enterprises, and women were excluded from every aspect of their operation. ${ }^{29}$ In this sense, the mines' masculinity was not the natural order, as Lahiri-Dutt reminds us. ${ }^{30}$ Peter Alexander has noted that family labour was generally associated with manual labour in smaller mines, and that the removal of women was linked to mechanization and the pressure to produce more efficiently. ${ }^{31}$

The exclusion of women seems to parallel the emergence and constitution of capitalism, considered here as a historical process of commodification that in

24. María Cristina Navarrete, Génesis y desarrollo de la esclavitud en Colombia, Siglos XVI y XVIII (Cali, 2005), p. I60.

25. Lucelly Villegas Villegas, Mineria y Trabajo independiente en Antioquía colonial. Los mazamorreros, $1778-1820$ (Medellín, I984), pp. 50 and 52.

26. Ann Twinam, Mineros, comerciantes y labradores. Las raíces del espiritu empresarial en Antioquía, $1763-1810$ (Medellín, 1985), p. 69.

27. Villegas Villegas, Minería y trabajo independiente en Antioquía colonial, pp. 84-88.

28. Claudia Leal, "Slave Mining and Emancipation", in idem, Landscapes of Freedom: Building a Postemancipation Society in the Rainforests of Western Colombia (Tucson, AZ, 20I8), pp. 33, 40-4I, 50-5 I.

29. Vanja, "Mining Women in Early Modern European Society", p. I I 5.

30. Kuntala Lahiri-Dutt, "Digging Women: Towards a New Agenda for Feminist Critiques of Mining”, Gender Place and Culture: A Journal of Feminist Geography, 2 (2012), pp. 193-2 I 2, I 93. 31. Peter Alexander, "Women and Coal Mining in India and South Africa, c. 1900-1940", African Studies 66:2-3 (2007), pp. 20I-222, 216. 
global terms had different rhythms, and included diverse labour regimes and technological changes with different outcomes and results. ${ }^{32}$ Several factors and variables need to be analysed in order to understand its links and connections to the history of mining in its varied manifestations: underground and surface mining; types of mineral; demand and prices; property rights and rules relating to exploitation; capital intensity or labour intensity; labour costs; labour organization and unions; type and size of enterprise; state intervention; ideologies; and gender relations. This complexity points to the need for more studies to identify and delineate a chronology, as well as the tendencies and specificities according to region and type of mineral. The case of coal mining in Great Britain is an example, and the prohibition on the work of women and children became more widespread across the world.

\section{Laws to protect women in the nineteenth and early twentieth centuries}

In general, it is believed that there were at least two moments when women were excluded from mines in modern Europe: after 1842 and after 1930 . However, it is important to make two qualifications here. On the one hand, according to Christina Vanja, by the eighteenth century women had largely disappeared from mining as part of a process of proletarianization in which mineworkers were transformed from small, independent, and petty producers into wage workers in large enterprises. ${ }^{33}$ On the other hand, as we will see, the measures taken in Great Britain in I 842 extended throughout Europe and even the world. In this sense, the regulations adopted by the International Labour Organization (ILO) after 1930 formalized a situation in which, with just a few exceptions, women no longer worked in underground mines.

In I 800 , Great Britain produced eighty per cent of the world's coal, and I I 8,233 men were employed in coal mining in England, Wales, and Scotland in I $84 \mathrm{I}$, while, according to official figures, only 2,350 women were, although the real figure might actually have been higher, between 5,000 and 6,000. ${ }^{34}$ The Mines and Collieries Act of 1842 banning women and children from coal mines was adopted after an enquiry ordered by Queen Victoria. According to Angela John's analysis of the debate surrounding the Act, arguments

32. Jürgen Kocka, A Short History of Capitalism (Princeton, NJ, 20I6); see also important contributions in idem and Marcel van der Linden (eds), Capitalism: The Reemergence of a Historical Concept (London, 2016).

33. Vanja, "Mining Women in Early Modern European Society", p. I०4.

34. George Richardson Porter, The Progress of the Nation in its Various Social and Economic Relations, Section V to VIII (London, I893), p. 79; William Frederick Spackman, An Analysis of the Occupations of the People Showing the Relative Importance of the Agricultural, Manufacturing, Shipping, Colonial, Commercial, and Mining Interests of the United Kingdom of Great Britain and its Dependencies. Compiled from the Census of I84I (London, I847); John, By the Sweat of Their Brow, pp. 24-25. 
were fuelled by the ambivalence of nineteenth-century attitudes towards the employment of working-class women, in which women miners were considered the very essence of degraded womanhood. ${ }^{35}$ Alan Heesom asserted that the Act's protagonists and opponents had complex motivations. There was a humanitarian aspect inspired by religious attitudes to children's education; there was also an interest in combatting what was considered an indecent occupation for women (who might be naked in the pits); finally, it was one aspect of factory regulation. ${ }^{36}$

Under the Mines and Collieries Act of I 842 , all females under eighteen were required to leave underground employment ${ }^{37}$ within three months. Women had to search for another job, and some of them continued to work above ground as "pit brow lasses" or on platforms upon which the coal was sorted and screened..$^{38}$ These pit brow women were regarded as an aberration in a masculine domain, a contradiction of the bourgeois ideal of home, which tore women from the household and her "natural sphere". ${ }^{39}$ A similar situation could be found in coal mines in France and Belgium with the prohibition of underground work for women, who then continued to work on the surface. ${ }^{40}$

The 1842 Act was considered "the first and one of the most extensively documented pieces of discriminatory labour legislation", ${ }^{4 \mathrm{I}}$ and the first time that "authorities limited the exploitation of a class of workers on the basis of gender, a distinction which has characterized protective labour legislation ever since" ${ }^{42}$ In France, the Law of I 874 prohibited underground work for girls and women. ${ }^{43}$

The Mines and Collieries Act of 1842 provided no financial compensation for women, forcing many to evade the law and placing some 5,000 women in a

35. John, By the Sweat of Their Brow, pp. 30-32, 37-60.

36. Alan Heesom, "The Coal Mines Act of 1842 , Social Reform, and Social Control”, The Historical Journal, 24:I (198I), pp. 69-88.

37. Angela V. John, "Colliery Legislation and its Consequences: 1842 and the Women Miners of Lancashire", Bulletin of the John Rylands Library, 6r:I (1978), pp. 78-1 I4, 8 I.

38. Idem, By the Sweat of Their Brow, pp. 69-93.

39. Ibid., pp. I36-I 59 .

40. Diana Cooper-Richet, Le peuple de la nuit. Mines et mineurs en France (XIXe-XXIe siècle) (Paris, 2002); Leen Roels, “'In Belgium, Women Do All the Work.' The Labour of Women in the Coalmines of Liege, Nineteenth-Early Twentieth Centuries", Revue belge d'histoire contemporaine / Belgisch tijdschrift voor nieuwste geschiedenis, 38:I (2008), pp. 45-86; Knotter, "Mining", pp. 252-253.

4I. Jane Humphries, "Protective Legislation, the Capitalist State, and Working-Class Men: The Case of the I 842 Mines Regulation Act”, Feminist Review, 7 (1981), pp. I-33, 7.

42. Ibid., p. 28.

43. Michele Bordeaux, "Nouvelle et périmée: La loi du I 9 mai I 874 sur le travail des enfants et des filles mineures employés dans l'industrie", in Jean-Pierre Le Crom (ed.), Deux siècles de droit du travail. L' histoire par les lois (Paris, 1998), pp. 45-59. 
precarious situation..$^{44}$ It is in this context that women wore men's clothes in order to pass as men in the pits. ${ }^{45}$

Women remained important in other parts of the world, such as India and Japan. In I 890, in India, around 25,000 labourers worked in Bengal's coal mines - a figure that had increased to I75,000 by 1919, while the number of women rose more rapidly than the number of men. Cutters working underground were predominantly men, while around 44 per cent of the loaders were women. In surface tasks, fifty-seven per cent of workers were men and thirty-five per cent women, the rest being children. ${ }^{46}$ In the coalfields of Jharia and Raniganj in 1924, around fifty-five per cent of the women working underground worked with their husbands, thirty per cent worked with their relatives, and twenty per cent on their own. Again, there was a distinct gendered division of labour: men cut the coal while their wives and children carried and hauled it. This family work system could also be found in the Kyushu coal mines in southern Japan, where, since the mid-nineteenth century, men hewed and women hauled. Until World War I, family work, including women's work, was promoted by many mining companies. In 1909, in Japan, around ten per cent of all women employed worked in mines and collieries. ${ }^{47}$ Women accounted for twenty-one per cent of all miners, seventeen per cent of those in metal mining, and twenty-five per cent of those in coal mining (Table I).

The numbers around 1924 are impressive because seventy-one per cent of women labourers were working underground. ${ }^{8}$ There was also an existing culture of women's involvement in mines and working above ground, while men laboured underground. The traditional system was associated with men digging the coal while women transported it to the surface and sorted it outside. ${ }^{49}$ There were, however, important regional differences even within Japan. In the Chikuho coal fields, husband and wife teams worked in the pits as coal diggers, and women accounted for thirty per cent of the pit workforce in the I $920 .^{50}$

44. John, "Colliery Legislation and Its Consequences”, p. 8 I.

45. Sara Horrell and Jane Humphries, "Women's Labour Force Participation and the Transition to the Male-Breadwinner Family, I790-1 865”, The Economic History Review, 48: I (1995), pp. 89II 7,98 .

46. Dietmar Rothermund and D.C. Wadhwa (eds), Zmindars, Mines and Peasants: Studies in the History of an Indian Coalfield and its Rural Hinterland (New Delhi, 1978), p. I87.

47. Regine Mathias, "Female Labour in the Japanese Coal-Mining Industry", in Janet Hunter (ed.), Japanese Women Working (London, 1993), pp. 99-1 22, 102-108.

48. Ibid., p. I०2; Knotter, "Mining”, p. 253.

49. Matthew Allen, "Undermining the Occupation: Women Coalminers in I 940 Japan", Journal of Multidisciplinary International Studies, 7:2 (2010), pp. I-I4, I-2.

50. Nimura Kazuo, The Ashio Riot of 1907: A Social History of Mining in Japan (Durham, NC, I997), pp. 3I-32. 
Table I. Males and females working in mining, Japan, 1909.

\begin{tabular}{lrrr}
\hline & Total & Male & Female \\
\hline Mining & 235,809 & 184,766 & 51,043 \\
Metal mining & 74,105 & 61,657 & 12,448 \\
Coal mining & 152,515 & 113,957 & 38,558 \\
Other mining & 9,189 & 9,152 & 37 \\
\hline
\end{tabular}

Source: Nimura Kazuo, The Ashio Riot of 1907: A Social History of Mining in Japan (Durham, NC, 1997), p. 17.

A second point at which women were excluded in much wider regions corresponds to the wave of legislation to protect women from the mid-nineteenth century to World War II. This period has to be understood in the context of escalating concerns in the West during the nineteenth and the early twentieth centuries about the impact of industrialization on the family lives of men and women. It is noteworthy that this new concern was combined with appeals to morality and the duties of motherhood, contributing to protective labour legislation to restrict women's hours and regulate their working conditions. ${ }^{\text {I }}$ The idea of home, family life, and motherhood was used also to exclude women from unions, while the "home-and-motherhood argument" restricted women's participation in the labour market. ${ }^{52}$ As research has shown, in many cases male domination of labour organizations played a crucial role in women's exclusion from work in the mines and in the removal of women from workers' organizations. ${ }^{53}$

The role of the ILO after I919 was vital in expanding coordinated social legislation developed mainly in response to a fear of widespread unrest. ${ }^{54}$ The first regulations regarding women in I9I9 show concern for their reproductive role: maternity leave in Convention 3; prohibition and limits on women working with lead in Convention 4; and prohibition on night work, also in Convention 4. Between I 929 and I933, the ILO considered working hours in coal mines, and, immediately after, the employment of women and young persons. Convention 45 in 1935 saw the prohibition on the employment of women in underground work in any mine. ${ }^{55}$ Convention 45 was

5. Susan Lehrer, Origins of Protective Labor Legislation for Women, 1905-1925 (New York, 1987); Ulla Wikander, Alice Kessler-Harris, and Jane Lewis (eds), Protecting Women: Labor Legislation in Europe, the United States, and Australia, I 890-1920 (Urbana, IL, I995).

52. Alice Kessler-Harris, Gendering Labor History (Urbana, IL, 2007), pp. 30-3 I, 36.

53. For Britain, see John, By the Sweat of Their Brow, pp. 57, 71; for a case in Australia, see Andrew Metcalfe, "Manning the Mines: Organising Women Out of Class Struggle", Australian Feminist Studies, 2:4 (1987), pp. 73-96.

54. Marcel van der Linden, "The International Labour Organization, I919-2019: An Appraisal”, Labor: Studies in Working-Class History of the Americas, I6:2 (2019), pp. I I-4I, I3.

55. International Labour Office (ILO), Women and Work: Selected ILO Policy Documents (Geneva, 1994). 
the result of a "Grey Report" prepared by the ILO and of a questionnaire sent to member states. Their replies revealed that, in most countries, women's employment underground was already prohibited (in Bulgaria; several states in Canada, including British Columbia, New Brunswick, Ontario; New Zealand; Union of South Africa; Brazil; Estonia; Netherlands; Belgium; Romania), and in some of them even surface work. The scope of the regulation, which included mines, extended, too, to other analogous places, such as quarries, gravel pits, sand pits, clay pits, and to "all persons of female sex", without any exception to the nature of substances extracted or the character of the working, "whether wholly or only partly underground". ${ }^{6}$ The Convention was adopted in 1935 and came into force in 1937; thirty-eight countries ratified it, meaning that the standards laid down were widely accepted and applied. 57 In article 2 of the Convention, the ILO accepted that "no female whatever her age shall be employed on underground work". ${ }^{8}$

Table 2 shows the years in which women's underground work was prohibited in ILO member states, and also shows that women's work in the mines, mainly underground, had already been prohibited by many countries before Convention 45 of 1935 . Some countries integrated a number of prohibitions in their mining legislation, others (like France and Chile) in more general labour legislation, or in laws concerning the employment of women (Italy, Greece, Peru, Argentina, Mexico, Bolivia), the employment of women and children together (like Austria, Estonia, Poland), number of hours worked in the mines or the eight-hour day (Spain, Czechoslovakia), or in worker protection (Sweden, Norway) and worker health and safety (Bulgaria, China, Dutch East Indies). ${ }^{59}$

From 1930 to 1935 , the ILO gathered information and data from member states, but although based on reports from various governments the information was not always precise. For example, in Spain the first restrictions on women working underground were not those enshrined in legislation on

56. Idem, Employment of Women on Underground Work in Mines of all Kinds, Report II (Geneva, 1935), pp. 33-39.

57. Idem, Convention Concerning the Employment of Women on Underground Work in Mines of all Kinds (Geneva, 1935), pp. I 2-1 3 .

58. Co45 - Underground Work (Women) Convention, 1935 (No. 45), Convention Concerning the Employment of Women on Underground Work in Mines of all Kinds (Entry into Force: 30 May 1937): available at https://www.ilo.org/dyn/normlex/en/f?p=NORMLEXPUB: 2 I $100: 0::$ NO:I 2 100:PI 2 I00_ILO_CODE:Co45; last accessed 20 July 2019.

59. ILO, Women's Work under Labour Law: A Survey of Protective Legislation (Geneva, I932); BIT, Conférence internationale du Travail, Emploi des femmes aux travaux souterrains dans les mines de toutes catégories, Rapport VI, Première discussion, dix-huitième session (Geneva, 1933); ILO, Employment of Women on Underground Work in Mines of all Kinds, Report VI, I 8th session (Geneva, I933); BIT, Conférence internationale du Travail, Emploi des femmes aux travaux souterrains dans les mines de toutes catégories, Deuxième question à l'ordre du jour, Rapport II, dix-neuvième session (Geneva, 1935). 
Table 2. Countries and years from which women were probibited from working in mines (up to 1933).

\begin{tabular}{|c|c|c|}
\hline Country & Year & Comments \\
\hline Great Britain & $\begin{array}{l}1842,1872 \\
1911\end{array}$ & \\
\hline Austria-Hungary & 1854 & \\
\hline France & 1874 & Labour and Social Welfare Code \\
\hline Luxembourg & 1876,1930 & \\
\hline Germany & 1878,1900 & Industrial Code, 1900 \\
\hline Australia & $1901-1929$ & $\begin{array}{l}\text { Mining legislation according to the } \\
\text { different states }\end{array}$ \\
\hline Netherlands & 1906 & \\
\hline Nicaragua & 1906 & \\
\hline Italy & 1907 & $\begin{array}{l}\text { Consolidated text of the Act on the } \\
\text { employment of women }\end{array}$ \\
\hline France - Tunis & 1910 & \\
\hline Spain & 1910 & Legislation on hours of work in mines \\
\hline South Africa & 1911 & \\
\hline Greece & 1912 & $\begin{array}{l}\text { Legislation on the employment of } \\
\text { women }\end{array}$ \\
\hline Sweden & 1912 & Workers' Protection Act \\
\hline Norway & 1915 & Workers' Protection Act \\
\hline British Empire-Newfoundland & 1916 & \\
\hline Canada & 1917-1925 & $\begin{array}{l}\text { Legislation according to the different } \\
\text { provinces }\end{array}$ \\
\hline British Empire - Nigeria & 1917 & \\
\hline Bulgaria & 1917 & Workers' Safety Act \\
\hline Czechoslovakia & 1918 & Legislation on the eight-hour day \\
\hline Peru & 1918,1929 & $\begin{array}{l}\text { Legislation on the employment of } \\
\text { women, } 1918 \text { Regulations of the } \\
\text { Mining Police, } 1929\end{array}$ \\
\hline Austria & 1919 & $\begin{array}{l}\text { Legislation on the employment of } \\
\text { young persons and women }\end{array}$ \\
\hline Belgium & 1919 & \\
\hline France - Algeria & 1921 & \\
\hline China & 1923 & $\begin{array}{l}\text { Legislation on the prevention of } \\
\text { accidents to miners }\end{array}$ \\
\hline Argentina & 1924 & $\begin{array}{l}\text { Legislation on the employment of } \\
\text { women }\end{array}$ \\
\hline Estonia & 1924 & $\begin{array}{l}\text { Legislation concerning the } \\
\text { employment of women and } \\
\text { children }\end{array}$ \\
\hline France - French Guiana & 1924 & \\
\hline Poland & 1924 & $\begin{array}{l}\text { Legislation on the employment of } \\
\text { young persons and women }\end{array}$ \\
\hline New Zealand & 1925,1926 & \\
\hline Guatemala & 1926 & $\begin{array}{l}\text { Labour Act, "persons of either sex } \\
\text { under the age of } 21 \text { " }\end{array}$ \\
\hline France - Morocco & 1926 & \\
\hline
\end{tabular}


Table 2. (Continued)

\begin{tabular}{|c|c|c|}
\hline Country & Year & Comments \\
\hline France - New Caledonia & 1927 & \\
\hline Portugal & 1927 & \\
\hline Japan & 1928 & Applied from 1933 with reservations \\
\hline Hungary & 1928 & \\
\hline Romania & 1928 & \\
\hline Venezuela & 1928 & $\begin{array}{l}\text { Underground work prohibited for } \\
\text { women under age under the } \\
\text { Labour Act }\end{array}$ \\
\hline $\begin{array}{l}\text { British Empire - Federated } \\
\text { Malay States }\end{array}$ & 1928 & \\
\hline British Empire - Gold Coast & 1928 & \\
\hline India & 1929 & $\begin{array}{l}\text { With reservations and gradually } \\
\text { enforced }\end{array}$ \\
\hline $\begin{array}{l}\text { British Empire - Mandated } \\
\text { Territory of Tanganyika }\end{array}$ & 1930 & \\
\hline Netherlands - Dutch East Indies & 1930 & $\begin{array}{l}\text { Legislation concerning health and } \\
\text { safety }\end{array}$ \\
\hline Bolivia & 1930 & $\begin{array}{l}\text { Underground work prohibited for } \\
\text { women under age under legislation } \\
\text { on the employment of women }\end{array}$ \\
\hline Chile & 1931 & Labour Code \\
\hline Mexico & 1931 & $\begin{array}{l}\text { Legislation on the employment of } \\
\text { women }\end{array}$ \\
\hline British Empire - British Guiana & 1931 & \\
\hline British Honduras & 1931 & \\
\hline Britain - Kenya & 1932 & \\
\hline Brazil & 1932 & \\
\hline France - Indochina & 1933 & \\
\hline
\end{tabular}

Sources: ILO, Women's Work under Labour Law: A Survey of Protective Legislation (Geneva, 1932), pp. 173-177; ILO, Employment of Women on Underground Work in Mines of all Kinds, Report VI, 18th session (Geneva, 1933), pp. 9-25; BIT, Conférence internationale du Travail, Emploi des femmes aux travaux souterrains dans les mines de toutes catégories, Deuxième question à l'ordre du jour, Rapport II, dix-neuvième session (Geneva, 1935), pp. 5-11.

the number of hours worked in mines in I910, as the ILO data suggested, but the Mining Police Regulations of 25 July i 897, which constituted the first law prohibiting women's work in underground mining in Spain. ${ }^{60}$ In Portugal, the first restriction on women's work underground in mines was regulated by the decree of I4 April I 89I and confirmed by the decree of I6 March I 893; this is much earlier than the 1927 claimed by the ILO as the date of the earliest government regulation on women mineworkers, during the Military Dictatorship

60. See the article in this Special Theme by Miguel Á. Pérez de Perceval Verde, Ángel Pascual Martínez Soto, and José Joaquín García Gómez. 
(1926-1933). ${ }^{61}$ In Italy, the first restrictions on women's work underground did not originate with the consolidated text of the 1907 Act on the employment of women, but five years earlier, in 1902, with the law on the employment of women and children, which prohibited women from working underground. The Italian law of 1907 was necessary though because there was no real control on the application of the 1902 law, and many mining industries simply ignored it. ${ }^{62}$ Similarly, in Greece the ban on female work underground was the result not of the law of I9 22 "On the labour of women and children" but of the I9ro mining law "On mines", which was the first legislation to prohibit the employment of women and children in jobs underground and night work in the mines. ${ }^{63}$ It should also be noted that some of the laws mentioned in Table 2 banned not only women's work underground but also at the surface (in the Netherlands, New Zealand, Peru), or at least especially laborious work (Austria, Bulgaria, Germany, China, Great Britain). ${ }^{64}$ In Bolivia and Guatemala, underground work was forbidden only for women under age. ${ }^{65}$

In its reports, the ILO stated that regulations were rare in colonial territories. However, India regulated underground work by women as early as I924, though there were important exceptions in the coal mines of Bengal, Bihar, and Orissa, and the regulation was only gradually enforced before i939. The percentage of women in coal mines fell from twenty-nine per cent in I929, to two per cent in 1939, and in the salt mines from forty per cent to four per cent. Nevertheless, several members of the Indian Mining Association believed that the "abolition of the employment of women underground should speed up". In Japan, in the major coal mines, which represented eighty per cent of the coal mines, the situation was similar. The reduction planned for the mines was to be implemented quickly: from 36,759 women working in more than $\mathrm{I} 98$ mines in $\mathrm{I} 928$, to $8, \mathrm{I} 46$ in $\mathrm{I} 36$ mines in $\mathrm{I} 93 \mathrm{I},{ }^{66}$ and to 6,000

6I. We are grateful to Paulo Guimarães from the University of Evora for this information. See also Paulo Eduardo Guimarães, Indústria e conflito no meio rural: Os mineiros alentejanos (I858-1938) (Evora, 200I), pp. 204-2 I I.

62. Legge "sul lavoro delle donne e dei fanciulli", i 9 luglio I902, Gazzetta Ufficiale del Regno, 7 July I902, n. I30: available at http://wwwi.unipa.it/storichedeldiritto/Materiali/FONTI/ Leggi_Cont/L_19-07-1902.html; last accessed 20 July 2019; Testo unico della legge sul lavoro delle donne e dei fanciulli: Approvato con Regio decreto Io novembre 1907, n. 8I 8, corredato di tutte le altre disposizioni legislative e regolamentari dal medesimo richiamate (Naples, 1908). See also Maria Vittoria Ballestrero, Dalla tutela alla parità: La legislazione italiana sul lavoro delle donne (Bologna, I979), pp. I I-19.

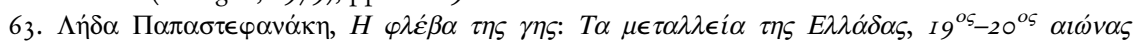
(Athens, 2017), pp. 57-59.

64. ILO, Women's Work Under Labour Law, p. 175; BIT, Emploi des femmes aux travaux souterrains, Rapport II, dix-neuvième session, p. Io.

65. ILO, Women's Work Under Labour Law, p. 175.

66. ILO, Employment of Women on Underground Work in Mines of all Kinds, Report VI, pp. I6-I7, 19. These numbers are higher than those given by Alexander, who wrote that between I9I 5 and I935 
by 1933. After that date, an exemption was permitted in small mines, and women might still be employed underground in mines where most of the veins were thin. ${ }^{67}$ Some mines in the region of Kyushu requested permission to postpone evicting women because doing so would affect the livelihood of miners' families, which were supported by women, potentially leading to "a serious situation". ${ }^{6}$

The role of the ILO as a supranational authority during the interwar was crucial for the promotion and implementation of global labour standards. ${ }^{69}$ The critique of feminist historians emphasizes that ILO conventions and recommendations "have not only reflected the male breadwinner ideal that unionized men struggled to realize" since the nineteenth century, but also that these instruments "gave member states guidance on how to deploy women workers, whether for the maintenance of people or the fashioning of goods and provision of services". ${ }^{70}$

The Underground Work (Women) Convention (No. 45, 1935), together with the Forced Labour Convention (No. 29, 1930) and the Recruiting of Indigenous Workers Convention (No. 50, 1936) can be seen in the intersection between the engendering of international labour law and the focus on the Global South in the process of the formation of international labour standards, which the ILO pursued in order to bring sex-specific protection to the Global South. As Zimmermann argues, the Underground Work (Women) Convention was a classic measure offering special protection for women

the proportion employed on underground activities who were women fell from six per cent to one per cent and the proportion working on the surface fell from five or six per cent to two per cent. Alexander, "Women and Coal Mining in India and South Africa", p. 207.

67. ILO, Women's Work under Labour Law, p. I76. Women were prohibited from undertaking the following work, some of which was performed underground: (i) cleaning, oiling, examining or repairing the dangerous parts of machinery; (ii) putting on or taking off the belts or ropes of machines or power transmission apparatus by a dangerous method; (iii) stoking a boiler or opening or shutting the feed water valve or the stop valve, or handling the safety valve; (iv) handling an electric generator, motor, transformer, commutator; (v) switching high tension lines; (vi) handling a winch operated by mechanical power; (vii) coupling or uncoupling trucks while in motion; (viii) the excavation of minerals or shovelling of rock; (ix) placing or firing shots; (x) erecting or removing props; (xi) handling very hot or molten minerals or slag at a refinery; (xii) cleaning flues or chimneys where noxious soot has accumulated; (xiii) work at a place where dust, fumes or gases from arsenic, mercury, lead or zinc or their compounds or other similar noxious substances are present; (xiv) work at a place where refining by electrolysis is performed; (xv) feeding furnaces with ore. See ILO, Employment of Women on Underground Work in Mines of all Kinds, Report VI, p. I 8.

68. ILO, Employment of Women on Underground Work in Mines of all Kinds, Report V, pp. 35-36. 69. For the ILO, see Van der Linden, "The International Labour Organization, I919-2019", pp. I I-4I.

70. Eileen Boris, "Beyond Separate Spheres", Labor: Studies in Working-Class History, I6:2 (2019), pp. 43-47, 44; see, also, Susan Zimmermann, "Equality of Women's Economic Status? A Major Bone of Contention in the International Gender Politics Emerging During the Interwar Period", The International History Review, 41:I (2019), pp. 200-227. 
with an unusual focus on the Global South. The preparation and adoption of the Underground Work (Women) Convention in the I930s occurred at the same time as the intensification of the conflict among women's organizations and networks over special labour protection. ${ }^{7 \mathrm{I}}$

Dhiraj Kumar Nite underlined how a number of welfare schemes relating to housing or schools were started, but with a complete absence of concern for how to ensure sufficient income for the breadwinner and the consequences of women being phased out of the underground mines. The author argues that in India forty-two per cent of the total underground workforce was evicted; this translates into a reduction in household earnings of forty per cent. $^{72}$ Recent studies have stressed how, instead of human considerations, the reforms were influenced by the transformation of the industry, including technological change. ${ }^{73}$

Together with other measures taken by the ILO in their conventions, the spectrum of work for women was restricted, except during wartime. ${ }^{74}$ Coal mines being associated with men and colonialism also affected societies in the twentieth century, as Carolyn Brown has shown for Enugu, where men were converted into "Boys", transforming also social relations. ${ }^{75}$

\section{Mechanization and masculinization}

The masculinization and hidden or veiled role of women in mines is also seen to be related to technological changes, to the underpinning of work by men in

71. Susan Zimmermann, "Globalizing Gendered Labour Policy: International Labour Standards and the Global South, I919-1947", in Eileen Boris, Dorothea Hoehtker, and Susan Zimmermann (eds), Women's ILO: Transnational Networks, Global Labour Standards, and Gender Equity, 1919 to Present (Leiden, 20I 8), pp. 227-254, 229-230, 238-24I. For the difference in ILO policies relating to European workers and indigenous workers, see Rossana Barragán, "La geografía diferencial de los derechos: Entre la regulación del trabajo forzado en los países coloniales y la disociación entre trabajadores e indígenas en los Andes (1920-1954)", in Laura Caruso and Ancrés Stagnaro (eds), Regular y Legislar el mundo del trabajo Latinoamericano. Aportes para una historia regional de la OIT (La Plata, 2017).

72. Dhiraj Kumar Nite, "Familist Movement and Social Mobility: The Indian Colliers (Jharia) 1895-1970", Indian Historical Review, 41:2 (2014), pp. 297-322, 305-307.

73. Peter Kirby, "Travail des enfants, risques professionnels et législation industrielle dans les industries textiles et minières en Grande-Bretagne au début du XIX e siècle", Le Mouvement Social, 249 (2014), pp. 91-1 I4, 93-95.

74. See, for example, for the production of iron, Stephanie Hemphill, "Women in the Mines", Minnesota History, 6I:3 (2008), pp. 92-10I, and for the coal mines in Japan see Mathias, "Female Labour in the Japanese Coal-Mining Industry", p. Iо6. See also Zimmermann, "Equality of Women's Economic Status?".

75. Carolyn Brown, "Race and the Construction of Working-Class Masculinity in the Nigerian Coal Industry: The Initial Phase, 1914-1930", International Labor and Working-Class History, 69: I (2006), pp. 35-56, 37-38. 
underground activities requiring strength or high levels of technology and machinery. ${ }^{76}$ The technological innovations are thought to explain the disappearance of activities in which women once participated. ${ }^{77}$ In collieries, for example, family work persisted as long as traditional stall-and-pillar mining prevailed. The mechanization of mining process and the replacement of stall-and pillar by long-wall mining together with the rationalization of production rendered the family system useless and women's labour underground redundant. Women's work in the mines above ground continued, as their work was considered "unskilled" and remunerated at a rate less than that of men; it was therefore cheaper. For the jobs above ground, when mechanization was introduced women's work became redundant. The gradual disappearance of women from mining work underground and in some cases above ground was a result of capitalist development and technological and organizational change, but it was also an outcome of the gender division of labour in the family and the workplace. Laurie Mercier has underlined this same directionality that mining work by women declined when operations became more capitalized, centralized, and mechanized..$^{8}$ Angela John, on the other hand, asserted that the mechanization and replacement of women by male labour eliminated pit women in Lancashire. Her study shows that the debates about women's work raised important questions concerning domestic ideology and the tradition of opposition to their work by the official unions. However, women colliery workers were also seen as heroines when they were required during World War I, but also quickly discarded thereafter. The author underlined how the use of mechanized tumblers to tip coal, washeries, and rapid loading schemes affected women, asserting that "the age of mechanization has swept them into history" ${ }^{79}$

In Japan, in the first few decades of the twentieth century, mechanization in large companies led to new methods and new ways of organizing labour. Manual mining was replaced by a digging machine operated by several men; automation was also introduced to recover the coal. But women still continued to sort coal. During the recession in the I 920 s they were laid off on the surface, and around 1928 women were formally banned from entering the coal mines even as haulers. Nevertheless, very soon, in the I930s, couples were working again and women were waste-haulers in larger companies, while in mediumsized companies and small labour-intensive mines they could be more

76. Dutt, "Digging Women”, p. I99; Laurie Mercier, "Bordering on Equality: Women Miners in North America", in Kuntala Lahiri-Dutt (ed.), Gendering the Field: Towards Sustainable Livelihoods for Mining Communities (Canberra, 201 I), pp. 33-47, 33-34, 43.

77. Vanja, "Mining Women", pp. I04, I I 5-I I7.

78. Mercier, "Bordering on Equality", p. 34.

79. Angela V. John, "Scratching the Surface: Women, Work and Coalmining History in England and Wales", Oral History, Iо:2 (1982), pp. I 3-26, I 5-16. 
important. Only after World War II were women in large companies no longer allowed to work down the mines. ${ }^{80}$

In almost all known cases world wide, technological change, mechanization, rationalization of production, together with the growth in large-scale mining and the ideology of the male breadwinner model seem to have resulted in the protection/eviction of women from underground work. However, the process seems to have been much more complex that one might imagine at first glance. Considering just technology, we are confronted with a variety of changes over time and in regions all over the world in the different stages of mining exploitation: extraction; ore processing; and transport. Technological innovation includes a wide variety of possibilities, from small to more major changes, and its magnitude could have very drastic and immediate effects, but also occur very slowly and over long spans of time. This evolution was certainly not linear, and mining today is revealing because there are mines worked predominantly by hand that coexist with others that are highly automated and that incorporate very sophisticated technologies, including digital innovation. There might also be a link between them along the commodity chains complicating even more the landscape of mining. The need for rapid returns in a world with high volatility in prices of minerals and with rapid resource depletion has always limited investment. The association between mechanization and masculinization that seems to be so evident therefore deserves further study and analysis in order to understand globally how technological changes were introduced and their consequences, taking into account as well the gender ideologies and asymmetries between men and women. There are many intervening variables that need to be considered in different parts of the world and in different periods, from the eighteenth to the twentieth century.

Studies so far show that in many parts of the world the "protection" of women and the social organization of the mining industry resulted in unequal relationships between men and women being reinforced. This is why also, in the second half of the twentieth century, and particularly in its final decades, the various forms of protection were questioned in the name of equality. The ILO concluded that, since 1975, the "special measures" or protective laws acted as an obstacle to the full integration of women in economic life ${ }^{8 \mathrm{I}}$ and hindered the aim of equal opportunity and treatment adopted in Convention I I in I 958 concerning discrimination in employment and occupation.

As Susan Lehrer reminds us, some feminists argued that the protective laws on women, inspired by capitalists or male workers, or both, served instead to discriminate against women. In this sense, what might appear to have been a

8०. Mathias, "Female Labour in the Japanese Coal-Mining Industry", pp. I02-108; Allen, "Undermining the Occupation", pp. 4-9.

8. ILO, Women and Work: Selected ILO Policy Documents, p. 5 I. 
benefit ended up as a policy against them. ${ }^{82}$ One factor that contributed to this situation is that employers and the state considered women to be expensive when social rights were involved..$^{83}$

In the United States, feminists compelled governments to open up jobs for women through equal employment opportunities. ${ }^{8}$ In some mining regions women demanded to be allowed to work in the mines, as happened in the famous Wyoming coal mines, where since the I970s and I980s one-fifth of all workers have been women. However, they were continuously confronted with having to demonstrate that they were able to deal with technology and acquire the skills necessary for their work. ${ }^{85}$ In India, from 1999-2000, the proportion of women working in the mines rose again, from three to twelve per cent. ${ }^{86}$ It is somehow paradoxical that the technological advances in the mining industry did not include women, while in several regions of the world women had to make a living in mines operating with low levels of capital and technology. The small mines and quarries are now the repository of the poorest workers, among whom women played and play a prominent role. ${ }^{87}$

\section{Women in artisanal small-scale mining and the informal economy}

Today, more than thirty-five million rural people are thought to be engaged in mineral extraction in developing countries, ${ }^{88}$ in the so-called artisanal and small-scale mining (ASM) characterized by low technology, intensive labour, low rates of production, and poor safety, health, and environmental conditions. ${ }^{89}$ Small-scale mining was first recognized as an industry by the United Nations in 1972, while the sector experienced rapid expansion after $19909^{\circ}$ This process can be seen in the light of the shifting changes in

82. Lehrer, Origins of Protective Labor Legislation for Women, pp. 4, I0-I I. On opposition to the I 842 Act, see Alan J. Heesom, "The Northern Coal-Owners and the Opposition to the Coal Mines Act of I 842", International Review of Social History, $25: 2$ (1980), pp. 236-27I.

83. Mercier, "Bordering on Equality", p. 35.

84. Ibid., p. 33 .

85 . Jessica Smith Rolston, “Talk about Technology: Negotiating Gender Difference in Wyoming Coal Mines", Signs: Journal of Women in Culture and Society, 35:4 (2010), pp. 893-91 8, 894. See also, Brown, "Race and the Construction of Working-Class Masculinity", pp. $35-56$.

86. Kuntala Lahiri-Dutt, "Roles and Status of Women in Extractive Industries in India: Making a Place for a Gender-Sensitive Mining Development", Social Change, 37:4 (2007), pp. 37-64, 56.

87. Ibid., p. 40.

88. Lahiri-Dutt, "Digging Women", p. 20 I.

89. Danellie Lynas, "A Good Business or a Risky Business: Health, Safety and Quality of Life for Women Small-Scale Miners in PNG”, in Kuntala Lahiri-Dutt (ed.), Between the Plough and the Pick: Informal, Artisanal and Small-Scale Mining in the Contemporary World (Acton, 2018), pp. I I-I70, Is I.

90. Gavin Hilson, "Small-Scale Mining, Poverty and Economic Development in Sub-Saharan Africa: An Overview”, Resources Policy, 34: I-2 (2009), pp. I-5. 
transnational corporations, which required fewer and more flexible labour. Some data show that in 1990 there were twenty-five million workers in the mining industry worldwide; by $2000,5.5$ million jobs had been lost. The system seems now to be based mainly on subcontracted mine workers. ${ }^{91}$ In the tin industry, for example, ninety-seven per cent of the world's production originates in developing countries, and at least forty per cent is produced by ASM. ${ }^{92}$

According to the ILO, in 1999 at least thirteen million people were directly employed in ASM, while roo million depended on it for their livelihood. Other estimates suggest that in the Global South around twenty-five million people are involved in ASM across more than seventy countries. Women constitute an important part of this workforce ${ }^{93}$ and they are particularly relevant in Africa, Asia, and Latin America, where they represent from ten to fifty per cent of the mining workforce (Table 3 ).

Women participate in almost every stage of mineral extraction, transport, and processing of minerals. In Burkina Faso and Mali, ninety per cent of these activities are in the hands of women. ${ }^{94}$ In other countries, such as the Democratic Republic of Congo, women are thought to account for twenty per cent of the mining workforce, and mining provides a living for between 0.8 and two million people. ${ }^{95}$ Women here are intermediaries between mineral buyers and artisanal miners, and play a crucial role in the local commodity chain..$^{96}$

Almost eighty per cent of all gemstones are mined artisanally. Women are employed in panning, washing, and processing. ${ }^{97}$ In the case of diamonds, before 1917, the Diamang Company in Angola worked with male and female labourers; in the last few decades of the twentieth century, women started to

91. Roger Moody, Rocks E Hard Places: The Globalization of Mining (London, 2007), p. 69; Jeb Sprague, "From International to Transnational Mining: The Industry's Shifting Political Economy and the Caribbean", Caribbean Studies, 43:I (2015), pp. 73-1 I 2, 69 and 76.

92. International Tin Association, International and Small-Scale Mining: available at www.internationaltin.org; last accessed 28 May 2019.

93. Natalia Yakovleva, "Perspectives on Female Participation in Artisanal and Small-Scale Mining: A Case Study of Birim North District of Ghana”, Resources Policy, 32:1-2 (2007), pp. 29-4I, 29-30. Jenkins speaks of around twenty-five million people across seventy countries, with women potentially accounting for at least one third. For an important review, see Katy Jenkins, "Women, Mining and Development: An Emerging Research Agenda", Extractives Industries and Society, I:2 (2014), pp. 329-339, 330.

94. Jenkins, "Women, Mining and Development", pp. 330-33 I.

95. Dorothea Hilhorst et al., Revenir à la Realité: Dynamiques de gouvernance et changement social dans l'exploitation minière artisanale et à petite échelle en RDC (Wageningen, 2016), p. 2: available at https://edepot.wur.nl/401777; last accessed 22 November 2019.

96. Marie-Rose Bashwira et al., "Not Only a Man's World: Women's Involvement in Artisanal Mining in Eastern DRC", Resources Policy, 40 (2014), pp. I09-I I6, I I 2.

97. Lynda Lawson, "Rice, Sapphires and Cattle: Work Lives of Women Artisanal and Small-Scale Miners in Madagascar", in Lahiri-Dutt, Between the Plough and the Pick, pp. I7I-192, I7I. 
Table 3. Estimated number of miners and percentage of women, selected countries, 2005-20I0.

\begin{tabular}{llll}
\hline Country & Continent & Estimated no. of miners & \% of women \\
\hline Bolivia & South America & 72,000 & 35 \\
Brazil & South America & 10,000 & - \\
Burkina Faso & Africa & $100,000-200,000$ & 45 \\
Central African Republic & Africa & 100,000 & - \\
China & Asia & $3,000,000$ & - \\
Congo & Africa & $2,000,000$ & 20 \\
Ecuador & South America & 92,000 & \\
Ghana & Africa & $180,000-200,000$ & 50 \\
India & Asia & $12,000,000$ & 30 \\
Indonesia & Asia & 109,000 & 10 \\
Laos PDR & Asia & & 50 \\
Malawi & Africa & 40,000 & 50 \\
Mali & Africa & 200,000 & 30 \\
Mongolia & Asia & $40,000-60,000$ & $10-30$ \\
Mozambique & Africa & 60,000 & - \\
Nepal & Asia & 120,000 & $40-50$ \\
Pakistan & Asia & 400,000 & - \\
Papua New Guinea & Asia & $50,000-60,000$ & 20 \\
Peru & South America & 30,000 & - \\
Philippines & Asia & $185,000-400,000$ & - \\
South Africa & Africa & 10,000 & 5 \\
Sri Lanka & Asia & 165,000 & 25 \\
Tanzania & Africa & 550,000 & 45 \\
Uganda & Africa & 196,000 & 30 \\
Zambia & Africa & 30,000 & 44 \\
Zimbabwe & Africa & $350,000-500,000$ & \\
\hline Source Ad & Ala & & \\
\hline
\end{tabular}

Source: Adriana Eftimie, et al., Gender Dimensions of Artisanal and Small-Scale Mining: A Rapid Assessment Took Kid (n.p., 2012), p. 7.

supply food to the company.$^{98}$ Gold exploitation is another arena for women. In Papua New Guinea, the gold industry can be dated to the late i 880 s and was dominated by Europeans until 1960. Today, at least thirty per cent of the workforce there are women, engaged in manual activities such as tailings, panning, and sluicing. ${ }^{99}$ In Ghana, gold-mining is a large-scale activity that comprises sixty-five per cent of all mining production, with 16,000 workers accounting for 66,000 jobs indirectly, while small and artisanal mining directly supports over one million individuals and creates additional employment for as many as five million. Women are omnipresent, engaged in work as ore

98. Todd Cleveland, "Feeding the Aversion: Agriculture and Mining Technology on Angola's Colonial-Era Diamond Mines, I917-1975”, Agricultural History, 92:3 (2018), pp. 328-350, 332. 99. Lynas, "A Good Business or a Risky Business". 
haulers and washers, and as service providers (supplying food, clothing, water, and light mine supplies). ${ }^{100}$ Women are also present in transporting ore and water, receiving salaries sixty per cent less than those paid to men. ${ }^{\text {IOI }}$ In India, fifty-seven per cent of those involved in the small and informal goldmining sector are women. ${ }^{102}$

In ASM, women's labour is the result of many socio-economic and cultural barriers (including lack of education, lack of training in mining techniques, lack of access to bank credit, minimal compensation). They perform heavy manual jobs in poor working conditions, with high percentages of occupational disease and accidents. ${ }^{103}$ Frequently, women are still working in family labour systems, as in the case of stone quarrying in eastern India; the labour contractors or owners find this system easier to manage. ${ }^{\mathrm{IO}}$

In contrast to the "protective measures" taken by the ILO in the I930s, today some global institutions such as the World Bank encourage the hiring of women because this is considered "good for business, good for development". ${ }^{\text {IOS }}$

This overview leads to more questions for the future than it can resolve. The emergence of large enterprises in coal, tin, iron, and other minerals, the creation of wage-workers in the mines, and technological advances necessitates a global history that could link these processes to the presence and eviction of women. The persistence, or growing importance, of women's work in small-scale and artisanal mining today, especially in the Global South as part of the globally connected mining industries, is a contemporary phenomenon that new research needs to historicize by focusing on ASM in the past. Given

ı००. James McQuilken and Gavin Hilson, Artisanal and Small-Scale Gold Mining in Ghana: Evidence to Inform an "Action Dialogue", p. I2: available at https://pubs.iied.org/pdfs/ I66I8IIED.pdf; last accessed 27 May 20 I9.

IоI. Lawson, "Rice, Sapphires and Cattle", p. I74.

I02. Kuntala Lahiri-Dutt, "Mainstreaming Gender in the Mines: Results from an Indonesian Colliery", Development in Practice, I6:2 (2006), pp. 2 I 5-22 I, 2 I 8.

I03. Jennifer J. Hinton, Marcello M. Veiga, and Christian Beinhoff, "Women and Artisanal Mining: Gender Roles and the Road Ahead", in Gavin M. Hilson (ed.), The Socio-Economic Impacts of Artisanal and Small-Scale Mining in Developing Countries (London, 2003), pp. I49i 88; Suzanne E. Tallichet, Meredith M. Redlin, and Rosalind P. Harris, "What's a Woman to Do? Globalized Gender Inequality in Small-Scale Mining”, in Hilson, Socio-Economic Impacts, pp. I89-20I; Crispin Kinabo, "Women and Small-Scale Mining in Tanzania", in Hilson, Socio-Economic Impacts, pp. 293-303; Kuntala Lahiri-Dutt, "Not a Small Job: Stone Quarrying and Women Workers in the Rajmahal Traps in Eastern India", in Hilson, Socio-Economic Impacts, pp. 403-424.

I04. Lahiri-Dutt, "Not a Small Job", pp. 413-417.

I05. According to the World Bank, "about 3.5 billion people live in countries rich in oil, gas or minerals [...]" and "non-renewable mineral resources play a dominant role in 8 I countries, which collectively account for a quarter of world GDP, half of the world's population, and nearly 70 per cent of those in extreme poverty". See http://www.worldbank.org/en/topic/extractiveindustries/overview, I4 November 2016. The slogan "good for business, good for development" is often quoted in several publications, mainly of the World Bank. 
that the processes of proletarianization and industrialization have never been uniform throughout the world, small, artisanal, and independent mining might have been more important than we think in some regions, and the role of women might have been seriously underscored in the past, particularly in the Global South. Clearly, it is fundamentally important to analyse the role of ASM over time, and to study the long-run evolution of the gendered division of labour and the segmentation of demand and supply. We do not know, for example, whether the inclusion of women in mining today is due to a less sharp gendered division of economic activities or to a contemporary geographical expansion of extractive activities all over the world, requiring labour on a scale that did not exist before and within particular conditions. The transnational transformation of industry is now associated with flexibilized labour, subcontractors, and exploratory firms. This implies that the separation between "informal" and "formal" mining is somehow misleading because, as Samaddar has noted, throughout the history of capitalism there has always been a mix of the two. Today, contemporary capitalism uses cheap labour throughout the global supply chain, "ordaining” the informal condition of labour, particularly in the extractive industries linked to neoliberal policies. ${ }^{\mathrm{I} O 6}$ In the case of Bolivia over the past decade, for example, a subsidiary enterprise of the Coeur d'Alene Mines Corporation used to buy the ores delivered by small artisanal miners without incurring the costs of extraction or the costs of labour. Here, there is a modus vivendi, with tensions between the state company, which has the legal lease of the mines and subleases them to the ASM (organized as cooperatives), which is characterized by informal, labour-intensive, minimally mechanized, and low-technology mining operations. ${ }^{107}$ There are connections and even a vertical integration between the formal sector and the small-scale and artisanal mining of the informal sector.

Although we have so far stressed the role of women as mine workers because this has generally been less emphasized in the literature, women were also in charge of their households, and much more, especially after being put aside as a consequence of legislation after the nineteenth century.

I06. Ranabir Samaddar, “Theorising Transit Labour in Informal Mineral Extraction Processes”, in Lahiri-Dutt, Between the Plough and the Pick, pp. I33-1 50.

107. See Rossana Barragán, "Silver, Tin and Lithium: Five Centuries of Mining in Bolivia or the Logic of Unsustainability", paper presented at the "Global Capitalism and Commodity Frontiers: A Research Agenda” workshop, 4-5 December 2015, International Institute of Social History, Amsterdam. See, also, Danilo Bocangel, Small-Scale Mining in Bolivia: National Study Mining Minerals and Sustainable Development (n.p., 200I), p. I I. Kathryn Robb et al., Indigenous Governance and Mining in Bolivia (St Lucia, 2015), p. 8; and Kirsten Francescone and Vladimir Díaz, "Entre socios, patrones y peones”, Petropress, 30 January 2013. 


\section{PRODUCTION AND REPRODUCTION IN THE MINES}

The activity of mining as centred on the work of men ignored the important domestic work carried out by women and children. The association of work with value in the eighteenth and nineteenth centuries meant that only those "activities that were performed for pay or that generated income" were regarded as value-producing. Work was progressively perceived as a commodity. Labour was defined as such only if it had market value, that is, if it could be measured in monetary terms. Activities necessary to individual and collective survival and well-being which had only a socially useful value were ignored and regarded as counter-productive work, because they did not produce goods destined for the market, and, being unpaid, were not considered an "occupation" or "employment". ${ }^{108}$

As activities of care and domestic tasks were frequently performed at home and mainly by women, this change towards "unproductive" labour was not gender neutral. The perception of tasks and skills (such as childcare, cooking, keeping the household, nursing) as being "natural" for women originated a new gendered division of labour in the workplace and at home: men were supposed to be the principal wage earners for their families; women were supposed to participate in secondary, auxiliary roles as wives, mothers, and housewives. ${ }^{\text {I09 }}$

Over the past forty years, feminist critique has repeatedly reconsidered the Marxist dichotomy between "productive" and "reproductive" labour, expanding the concept of work to include non-monetized subsistence and family activities illustrating the diversity of ways in which "reproduction is production over time and space", challenging the "naturalization" of homework. ${ }^{110}$ Feminist historians have also recognized the gendered division of labour within the forms of subsistence production and highlighted "the power relations within family and home", while they have also investigated the "structural impact" of non-paid labour by women in families and households. ${ }^{\text {II }}$ Moreover, research has often questioned the significance of the sole male breadwinner family, focusing on the workforce that had been neglected, specifically women and children. It is noteworthy that the male breadwinner family has its origins in Western family ideology. ${ }^{\mathrm{II} 2}$

108. Sarti, Bellavitis, and Martini, "Introduction", in idem, What is Work?, pp. I 5-22; quotation on p. Is.

I09. Ibid.; Boris, "Subsistence and Household Labour"; Boris, "Reproduction as Production", pp. I-I6.

I Io. Boris, "Reproduction as Production", p. 2; idem, "Subsistence and Household Labour"; Pescarolo, "Productive and Reproductive Work", pp. I I4-I 38.

I I I. Boris, "Subsistence and Household Labour", p. 33 I.

I I 2. Angélique Janssens, "The Rise and Decline of the Male Breadwinner Family? An Overview of the Debate”, International Review of Social History, 42:S5 (1997), pp. I-23. 
As has been shown by research all over the globe, the household or family budget comprises various incomes: monetary and non-monetary goods and services from different social relations of paid and unpaid work. It has also highlighted the central role of unpaid work in the maintenance of the family and the household, while recent research has also explored the diversity of adaptive family economies. ${ }^{\mathrm{II}}$

In mining communities, women's work was essential to the well-being of miners' families, as women were responsible for housekeeping and childcare. Recent research has explored new sources, such as oral testimonies and autobiographies, to trace women's everyday life in mining communities and to depict the unpaid work of women in the reproductive sphere of the mining families. As Valerie G. Hall has noted for coal-mining communities in England,

the nature of work in the mine and the culture of the miners meant a heavy domestic role for wives $[\ldots]$ Work in the pit was both dangerous and arduous and was conducted in terrible conditions [...] The routine of the household revolved around the routine of the pits and the needs of the miners, ${ }^{\mathrm{II}}$

as women were obliged to prepare baths and meals and wash the work clothes of the men according to the shifts of the male miners in every family. ${ }^{\text {II }}$ Women's household and cooking skills were more than crucial for the existence of the family in times of crisis, unemployment, or underemployment. ${ }^{\mathrm{I} 6}$ Moreover, in many mining communities women in England, Belgium, France, and the Mediterranean region were responsible for creating a clean and comfortable domestic environment for the miners, and for ensuring a modest lifestyle. ${ }^{1{ }^{17}}$

II3. Joan Smith, Immanuel Wallerstein, and Hans Dieter Evers (eds), Households and the World-Economy (Beverly Hills, CA, I984); Joan Smith, "Women's Unwaged Labour and the Formation of the World Labour Force", in Erik Aerts et al. (eds), Women in the Labour Force: Comparative Studies on Labour Market and Organization of Work since the I8th century (Leuven, 1990), pp. 8-16; Manuela Martini and Anna Bellavitis, "Household Economies, Social Norms and Practices of Unpaid Market Work in Europe from the Sixteenth Century to the Present", The History of the Family, 19:3 (2014), pp. 273-282; Anna Bellavitis, Manuela Martini, and Raffaella Sarti, "Une histoire de la famille à part entière?", Mélanges de l'École française de Rome. Italie et Méditerranée modernes et contemporaines, I 28:1 (2016); Manuela Martini and Leda Papastefanaki, "Introduction: Des économies familiales adaptatives en temps de crise dans l'Europe méditerranéenne", The Historical Review / La Revue Historique, is (2018), pp. 9-22.

I 4. Valerie G. Hall, Women at Work, I860-1939: How Different Industries Shaped Women's Experiences (Woodbridge, 2013), pp. $25-26$.

I I . Ibid., pp. 25-30, 59-6I.

I 16. Ibid., pp. 5 I- 52 ; Francesca Sanna, “La famille et l'OST: effets divergents de la rationalisation dans l'industrie minière de l'Europe du Sud pendant l'entre-deux-guerres”, The Historical Revue / La Revue Historique, is (2018), pp. 57-90.

i 17. Hall, Women at Work, p. 30; Joeri Januarius, "Picturing the Everyday Life of Limburg Miners: Photographs as a Historical Source", International Review of Social History, 53:2 
Besides, the hazards of mining and their consequences were part of the mining families' daily lives: the threats of death and injury, the black lung, the threats of unemployment and illness. Miners' wives had to manage their daily lives in the face of such threats, while shift work caused numerous problems in the daily life of the family. Women's attitudes to this harsh existence depended on the cultural tradition of each mining community and on the resilience, flexibility, and endurance of the people themselves. ${ }^{118}$ As Carol Giesen put it, "the [miners] men faced the dangers every day but it was the women who 'carried the mine in them'". ${ }^{19}$ Through good homemaking and childcare, by bearing the bulk of the family's responsibilities, the miners' wives supported their husbands, and usually felt a certain pride in doing so. ${ }^{120}$

To transform migrant rural labourers into a permanent and trained labour force, mining enterprises used to offer various facilities for workers and their families (accommodation, schools, healthcare, etc.) and implemented gendered social welfare policies. This seems to have been the case in a number of mines, including copper mines in Chile, Zambia, and Congo, ${ }^{\mathrm{I2I}}$ and in lead and iron mines in Greece during the nineteenth and twentieth centuries. ${ }^{122}$ In Europe and North America, the miner's family was at the centre of various paternalistic policies designed to control and ensure the stability of labour. According to the gendered ideology of domesticity, usually originating in Victorian middle-class values, women were responsible for housekeeping, care of the children, and the well-being of the family, but this gendered ideology interconnected with the male miner's productivity in the workplace. ${ }^{\mathrm{I} 23} \mathrm{In}$ Sweden, many mine owners encouraged miners to marry and bring their wives

(2008), pp. 293-3 I 2; Januarius, "Feeling at Home: Interiors Domesticity, and the Everyday Life of Belgian Limburg Miners in the I950s", Home Cultures, 6: I (2009), pp. 43-70; Sanna, "La famille et l'OST".

I 1 8. Carol A.B. Giesen, Coal Miners' Wives: Portraits of Endurance (Lexington, 1995).

I19. Ibid., p. 4 .

I 20. Ibid., pp. 8, I 2; Valerie Gordon Hall, "Contrasting Female Identities: Women in Coal Mining Communities in Northumberland, England, 1900-1939”, Journal of Women's History, I 3:2 (200I), pp. I07-I 3 I, I I 3; Sanna, "La famille et l'OST".

I 2 I. Thomas Miller Klubock, "Working-Class Masculinity, Middle-Class Morality, and Labor Politics in the Chilean Copper Mines", Journal of Social History, 30:2 (1996), pp. 435-463; Knotter, "Mining”, pp. 249-250.

I 2. Christine Agriantoni, "Spaniolika et Kyprianos: deux petites cités ouvrières à Lavrion", L'archéologie industrielle en France, 24-25 (1994), pp. I43-1 52; П $\alpha \pi \alpha \sigma \tau \epsilon \varphi \alpha v \alpha \dot{\alpha} \eta, H \varphi \lambda \varepsilon \dot{\beta} \alpha \tau \eta \varsigma$ $\gamma \eta$, pp. I90-193, I97-200.

I 23. See also the article by Leda Papastefanaki in this Special Theme. For different versions of European paternalism in the mines, see Donald Reid, "Industrial Paternalism: Discourse and Practice in Nineteenth-Century French Mining and Metallurgy", Comparative Studies in Society and History, 27:4 (1985), pp. 579-607; Louise Tilly, "Coping with Company Paternalism: Family Strategies of Coal Miners in Nineteenth-Century France", Theory and Society, I4:4 (I985), pp. 403-4I7; Cooper-Richet, Le peuple de la nuit, pp. 28-30, 36-37, 4I-44; Sanna, "La famille et l'OST"; Januarius, "Picturing the Everyday Life of Limburg Miners", pp. 293-3 I2; Januarius, "Feeling at Home”, pp. 43-70. For North American paternalism, see, 
and families with them, as they believed that married men could be more productive and family life created a harmonious milieu of social order and stability. ${ }^{\mathrm{I} 4}$

The important reproductive tasks of miners' wives and daughters in the mining family are closely related to the mechanization and rationalization of mining work, now performed exclusively by men, as their strenuous efforts, in day and night shifts, were possible only with a caring homemaker. There seems to have been a correlation between the mechanization and rationalization of the mining process with the removal of women because of the replacement of family teams, the intensification of mine work owing to technological change, and the relegation of women to housewives and homemakers. ${ }^{\mathrm{I} 25}$

Although in mining communities, women and girls had limited options for paid work outside the home, ${ }^{\mathrm{I} 26}$ they managed the family budget or contributed to the family income through many informal activities. Invisible women's labour in the mines and in mining areas tended to take the form of informal paid or unpaid activities (such as taking in lodgers, taking in laundry, baking bread, sewing, being engaged in small-scale subsistence agriculture). ${ }^{127}$ Women's contribution to family income was extremely important in times of crisis, illness, or unemployment. In the case of the Sardinian mines in I940s and I950s, women could contribute to the family's income through their waged work in the mines and by helping to buy the land on which to build the family house. ${ }^{\mathrm{I} 28}$ In South Africa's coal-mining areas, women were responsible for agricultural production and diverse forms of reproduction (from preparing food to selling sex). ${ }^{\mathrm{2}}{ }^{29}$ The prostitution that developed in mining regions and company towns in diverse national and colonial contexts from the mid-nineteenth century seems a permanent and complex phenomenon of capitalist development. ${ }^{\mathrm{I}}{ }^{30}$

Women created diverse networks of sociability and solidarity in the mining communities. Valerie Gordon Hall has challenged the strict division of labour

among others, Crandall A. Shifflett, Coal Towns: Life, Work, and Culture in Company Towns of Southern Appalachia, I880-1960 (Knoxville, TN, I99I).

I 24. Eva Blomberg, "Gender Relations in Iron Mining Communities in Sweden, 1900-1940", in Gier and Mercier, Mining Women, pp. I $25-\mathrm{I} 29$.

I 25. Valerie G. Hall, Women at Work; Knotter, “Mining”, pp. $25 \mathrm{I}-252$.

I26. Valerie G. Hall, Women at Work, pp. 22-23.

I 27. Hall, “Contrasting Female Identities”, pp. I07-I 3 I; Hall, Women at Work, pp. 24-25, 5 I-53; Kayoko Yoshida and Reiko Miyauchi, "Invisible Labor: A Comparative Oral History of Women in Coal Mining Communities of Hokkaido, Japan, and Montana, USA, I890-1940”, in Gier and Mercier, Mining Women, pp. I36-1 52; Knotter, "Mining”, pp. $250-252$.

I 28. Liliosa Azara and Eloisa Betti, "Fonti orali per la storia del lavoro nel Parco Geominerario della Sardegna: Orgoglio identitario e nostalgia”, Storicamente. Laboratorio di storia, I4 (2018), p. I 4 .

I 29. Alexander, "Women and Coal Mining in India and South Africa", p. 2 I 4.

I30. Julia Ann Laite, "Historical Perspectives on Industrial Development, Mining, and Prostitution", The Historical Journal, 52:3 (2009), pp. 739-76r. 
among male miners and housewives even in "homogenous" patriarchal coalmining communities by pointing to the variability of female identities among "housewives" and "political women" and activists. As she argues, in the period 1900-1939 women in Northumberland adopted new ideologies, such as feminism and socialism, while forging new political identities. ${ }^{\text {I3 }}$ Before World War II, in Yubari, a coal-mining town in Japan, women created networks of sociability, with gatherings for tea, discussions, and sewing lessons. Because of the cramped space in the houses provided by the mining company, these women had to leave their homes and go somewhere "to kill time", to allow their husbands to sleep quietly after a night shift in the mines. Gradually, these women's gatherings and informal support system became a formal system of mutual aid when the mine workers' unionized. At the end of World War II, women supported union organization among miners. ${ }^{132}$

Marcel van der Linden has suggested that, since there were several household strategies available to households to improve their living conditions, it might be important to analyse the different forms of activism among women and households. ${ }^{133}$ In mining communities, limited economic alternatives and the gendered division of labour often led women to regard their interests as closely tied to those of their husbands and fathers. Jaclyn Gier and Laurie Mercier have noted that abundant historical examples from mining communities worldwide "reveal how women exaggerated gender claims to secure solidarity for what they viewed as family and community, not just union, efforts". ${ }^{\mathrm{I} 4}$ We can trace many different traditions of protest for women in mining communities around the world, depending on the particular historical context. Women were often committed to activism and participated actively in industrial disputes and miners' strikes (in the great coalminers' strike in Anzin, France, in 1884 , or the Southern Colorado coal strike in I9I3-I9I4 for instance) and in some cases in the political struggles of miners. ${ }^{135}$ One example was the case of "Women against Pit Closures" during

I 3 I. Hall, "Contrasting Female Identities".

I32. Yoshida and Miyauchi, "Invisible Labor", pp. I43-144.

I33. Marcel van der Linden, "Connecting Household History and Labour History", International Review of Social History, 38:S I (1993), pp. I63-173.

I 34. Jaclyn J. Gier and Laurie Mercier, "Gender, Mining Communities, and Labor Protests, I900I960", in idem, Mining Women, p. I7I.

I 35. See, among others, Barbara Kingsolver, Holding the Line: Women in the Great Arizona Mine Strike of 1983 (New York, 1989); Hall, Women at Work, pp. 42-49, 66-77; Michelle Perrot, Les ouvriers en grève. France I 87I-I 890, 2 vols (Paris, I973), I, pp. 369-375; Cooper-Richet, Le peuple de la nuit, pp. 222-226; Gier and Mercier, "Gender, Mining Communities, and Labor Protests”, pp. I72-I79; Bonnie Stepenoff, “'I’m a Johnny Mitchell Man': Gender and Labor Protest in the Pennsylvania Hard Coal Uprising, 1900-1902", in Gier and Mercier, Mining Women, pp. I8I-I94; Anthony DeStefanis, "Violence and the Colorado National Guard: Masculinity, Race, Class, and Identity in the 1913-1914 Southern Colorado Coal Strike", in Gier and Mercier, Mining Women, pp. I95-2 I 2; Jaclyn J. Gier, "Mining Women Find a Voice: 
the $1984-1985$ miners' strike in Britain, ${ }^{136}$ when the promotion of gay and lesbian concerns within the labour movement was combined with the construction of new solidarity networks. ${ }^{137}$ At least in one case, during the long Empire Zinc strike in New Mexico in I950-1952, women came to rebel not only against the mining company but also against their husbands. ${ }^{138}$

\section{PRESENTATION}

Women were mine workers, but they were also responsible for their households, contributing as well to the income of their families and to their struggles. In this Special Theme, we present three different case studies (from Bolivia in the sixteenth to the eighteenth centuries, Spain, and Greece between I 860 and I940) that illuminate the variety of women's experience in the mines and the shaping of gender relations. The first study analyses silver production in Potosí during Spanish rule, when women did not work underground but did play a crucial role in surface activities. The second scrutinizes women's work in the mines in Spain much later, while the third focuses much more on how gender relations shaped the whole industry.

In her article "Women in the Silver Mines of Potosí: Rethinking the History of 'Informality' and 'Precarity' (Sixteenth to Eighteenth Centuries)", Rossana Barragán Romano focuses on the direct involvement of women in silver production, refining, and trade. She reconsiders and historicizes what it is now called "informal" labour and the artisanal and small-scale mining (ASM) associated with precarity and re-reads the history of mining in Potosí. The article argues that formal and informal employment developed at the same time because they exist in relation to one another. Barragán reconstructs how indigenous women played a crucial role in the early period of Potosí, between I 545 and I575, underlining the complex process of work and division of labour that emerged later on. One of her main contributions to the analysis of silver mines is to show that a circuit based on small and independent workers developed in the second half of the eighteenth century and that women were actively involved in refining ore in rudimentary mills or trapiches, selling the silver obtained to the Bank of San Carlos.

\footnotetext{
Working Class and Environmental Feminism in the Twenty-First Century”, in Gier and Mercier, Mining Women, pp. 326-334.

I 36. Jean Spence and Carol Stephenson, “'Side by Side with Our Men?' Women's Activism, Community, and Gender in the 1984-1985 British Miners' Strike”, International Labor and Working-Class History, 75: I (2009), pp. 68-84.

I37. Diarmaid Kelliher, "Solidarity and Sexuality: Lesbians and Gays Support the Miners I9845”, History Workshop Journal, 77:I (2014), pp. 240-262.

I38. Ellen Baker, "I Hate to Be Calling Her a Wife Now': Women and Men in the Salt of the Earth Strike, I950-1952", in Gier and Mercier, Mining Women, pp. 213-233, 218-220.
} 
In their article on "Female Workers in the Spanish Mines, I 860-I 940", Miguel Á. Pérez de Perceval Verde, Ángel Pascual Martínez Soto, and José Joaquín García Gómez study the direct employment of women in the mines in the golden age of this industry in Spain. The authors show clearly that the mining regulations at the end of the nineteenth century prohibiting the employment of women in underground mining in Spain legalized the prevailing situation. Women were therefore concentrated mainly in surface work, with important differences: they accounted for around five per cent of the total surface workforce, although in some exceptional cases, as in the manganese mines, women comprised thirty-three to fifty per cent in the Huelva region between 1902 and I934 and twenty per cent in the Asturias mines, dropping to ten per cent in I93 I-I934. This study shows also the enormous gender wage gap (they earned just forty per cent of the average wage of men who worked on the surface), which widened after 1920. The removal of women from the mines was considered an improvement for the working class, and the trade unions supported this policy. Although women participated actively in the most important mining conflicts, the reports did not mention any female "voice".

In her article "Family, Gender, and Labour in the Greek Mines, I8601940", Leda Papastefanaki argues that there are gender relations in the division of labour in the workplace, as well as in the family in mining communities. Her essay analyses the intersection between gender, family, and labour in some exemplary mining areas, such as Lavrion, Seriphos, and Euboea. She argues that the migration trajectories of the miners have gendered dimensions at both ends - in the place of origin and in the mining areas - as miners' migration was supported by the family in many ways. The control of migrant labour in mining areas interconnected with paternalistic policies of the companies that aimed to stabilize the workforce and create an attractive family environment to encourage and attract them to stay. Papastefanaki focuses on the gendered division of labour in Greek mines, which underlay women's inferior status in the mining process. An important contribution of this study is to underline the multiple meanings of the concept of "skilled labour" determined by the gendered social relations of power: the "risk-taking" character of male miners in comparison with the work performed by women and children on the surface, which was considered "unskilled" and "auxiliary".

\section{A NON-EXHAUSTIVE BIBLIOGRAPHY ON WOMEN AND MINING (2006-20I9)}

Alexander, P., "Women and Coal Mining in India and South Africa, I9001940", African Studies, 66:2-3 (2007), pp. $20 \mathrm{I}-222$.

Allen, M., "Undermining the Occupation: Women Coalminers in I940s Japan", Journal of Multidisciplinary International Studies, 7:2 (2010), pp. I-I4. 
Azara, L. and E. BetTi, "Fonti orali per la storia del lavoro nel Parco Geominerario della Sardegna. Orgoglio identitario e nostalgia", Storicamente. Laboratorio di Storia, I4 (2018), pp. I-I 8.

BAINTON, N.A., "Migrants, Labourers and Landowners at the Lihir Gold Mine, Papua New Guinea", in Colin Filer and Pierre-Yves Le Meur (eds), Large-Scale Mines and Local-level Politics: Between New Caledonia and Papua New Guinea (Canberra, 2017), pp. 31 3-35 I.

Baker, E., “'I Hate to be Calling Her a Wife Now': Women and Men in the Salt of the Earth Strike, 1950-1952", in Jaclyn J. Gier and Laurie Mercier (eds), Mining Women: Gender in the Development of a Global Industry, 1670 to the Present (New York, 2006), pp. 2 I 3-232.

Banchirigah, S.M. and G. Hilson, "De-Agrarianization, Re-Agrarianization and Local Economic Development: Re-Orientating Livelihoods in African Artisanal Mining Communities”, Policy Sciences, 43:2 (2010), pp. I $57-180$.

Banks, G., D. Kuir-Ayius, D. Kombako and B.F. Sagir, "Dissecting Corporate Community Development in the Large-Scale Melanesian Mining Sector", in Filer and Le Meur (eds), Large-Scale Mines and Local-Level Politics, pp. 207-228.

BASHWira, M.R., Revenir à la réalité. Dynamiques de gouvernance et changement social dans le secteur minier (semi) artisanal en RDC. Conditions de subsistence de femmes et diversité de réponses aux mutations du secteur minier artisanal en RDC orientale (Wageningen, 20I6).

Bashwira, M.R., J. Cuvellier, D. Hilhorst and G. van der Haar, "Not Only a Man's World: Women Involvement in Artisanal Mining in Eastern D.R.C.”, Resources Policy, 40 (2014), pp. I09-I I6.

Bellavitis, A. and M. Martini, "Household Economies, Social Norms ad Practices of Unpaid Market Work in Europe from the Sixteenth Century to the Present", The History of the Family, 19:3 (2014), pp. 273-282.

Bellavitis, A., M. Martini and R. SARTi, "Une histoire de la famille à part entière?", Mélanges de l'École française de Rome. Italie et Méditerranée modernes et contemporaines, I 28:I (20I6).

BenYA, A., "Going Underground in South African Platinum Mines to Explore Women Miners' Experiences”, Gender and Development, 25:3 (2017), pp. 509-522.

Benya, A., "Women, Subcontracted Workers and Precarity in South African Platinum Mines: A Gender Analysis”, Labour, Capital and Society/ Travail, capital et société, 48:I-2 (20I 5), pp. 68-9I.

Blomberg, E., "Gender Relations in Iron Mining Communities in Sweden, 1900-1940", in Gier and Mercier (eds), Mining Women, pp. I 19-1 35.

Boris, E., "Beyond Separate Spheres", Labor: Studies in Working-Class History, 16:2 (2019), pp. 43-47.

Boris, E., "Reproduction as Production: Thinking with the ILO to Move Beyond Dichotomy”, Labor and Society, 22 (2019), pp. 283-298. 
BORIS, E., "Subsistence and Household Labour", in Karin Hofmeester and Marcel van der Linden (eds), Handbook Global History of Work (Berlin, 2018), pp. 329-344.

Bouysse Cassagne, T., "Les mines d'or des Incas, le Soleil et les cultures du Collasuyu", Bulletin de l'Institut français d'études andines, 46:I (2017), pp. 9-36.

Bradshaw, S., B. Linneker and L. Overton, "Extractive Industries as Sites of Supernormal Profits and Supernormal Patriarchy?", Gender and Development, $25: 3$ (2017), pp. 439-454.

BRown, C., "Race and the Construction of Working-Class Masculinity in the Nigerian Coal Industry: The Initial Phase, 1914-1930", International Labor and Working-Class History, 69 (2006), pp. 35-56.

Brown, K.W., A History of Mining in Latin America: From the Colonial Era to the Present (Albuquerque, 2012).

Bryceson, D.F., "Artisanal Gold-Rush Mining and Frontier Democracy: Juxtaposing Experiences in America, Australia, Africa and Asia", in Lahiri-Dutt (ed.), Between the Plough and the Pick, pp. 3 I-62.

Bucar, E.M., "Saving Face: Navigating Land Mines with Ritual Politeness in Iran", History of Religions, 52:I (20I2), pp. 3 I-48.

Buitrago Orozco, D.C. and R.B. Perks, "Closing the Gender Gap in Extractives: What Has Been Done and What Have We Learned?", Live Wire Knowledge Note series, 87 (Washington, DC, 2018), pp. I-8.

Burton-Macleod, J., J. Jackson and C. Maddox, "Influence of South African Legislation on India's Mines and Minerals Bill: Problems and Perils”, Economic and Political Weekly, 47:40 (201 2), pp. 74-8I.

Burton, J. and J. Onguglom, "Disconnected Development Worlds: Responsibility towards Local Communities in Papua New Guinea", in Filer and Le Meur (eds), Large-Scale Mines and Local-Level Politics, pp. 26I-290.

Cahir, F., "Aboriginal People and Mining”, in Fred Cahir (ed.) Black Gold: Aboriginal People on the Goldfields of Victoria, I850-I870, (Canberra, 20I 2), pp. 5-20.

Chowdhury, A.R. and K. Lahiri-Dutt, "Agrarian Distress and Gemstone Mining in India: The Political Economy Of Survival”, in Lahiri-Dutt (ed.), Between the Plough and the Pick, pp. 89-i is.

Cleveland, T., "Feeding the Aversion: Agriculture and Mining Technology on Angola's Colonial-Era Diamond Mines, 1917-1975", Agricultural History, 92:3 (2018), pp. 328-350.

Cuvelier, J., "Work and Masculinity in Katanga's Artisanal Mines", Africa Spectrum, 49:2, (2014), pp. 3-26.

Davison, C.M. and P. Hawe, "All That Glitters: Diamond Mining and Tåîchô Youth in Behchokö, Northwest Territories", Arctic, 65:2 (June 20I2), pp. 214-228. 
De Theije, M. and T. Salman, "Conflicts in Marginal Locations: Small-Scale Gold-Mining in the Amazon", in Lahiri-Dutt (ed.), Between the Plough and the Pick, pp. 26I-274.

DeStefanis, A., "Violence and the Colorado National Guard: Masculinity, Race, Class, and Identity in the I9I3-19I4 Southern Colorado Coal Strike", in Gier and Mercier (eds), Mining Women, pp. 195-2 I 2.

Díaz, V. and K. Francescone, "Cooperativas mineras: Entre socios, patrones y peones", Petropress, 30 (2013), pp. 32-4I.

Donahue, K.C., "Tanzanite: Commodity fiction or commodity nightmare?" in Lahiri-Dutt (ed.), Between the Plough and the Pick, pp. 63-88.

Eftimie, A., K. Heller, J. Hinton, K. Lahiri-Dutt, N. Mutemeri and J. Strongman, Gender Dimensions of Artisanal and Small-Scale Mining: A Rapid Assessment Tool Kit. World Bank Report. (Washington, DC, 20I2).

Ferry, E.E., "Waste and Potency: Making Men with Minerals in Guarajuato and Tucson", Comparative Studies in Society and History, 53:4 (201 I), pp. 9I 4-944.

Figueroa, V., G. Manríquez, P. Núñez-Regueiro, D. Salazar and H. Salinas, "Pre-Hispanic Mining Ergology of Northern Chile: An Archaeological Perspective", Chungara (Revista de Antropología Chilena), 45:I (20I3), pp. 6I-8I.

Filer, C. and P.-Y. Le Meur, "The Large-Scale Mines and Local-Level Politics", in Filer and Le Meur (eds), Large-Scale Mines and Local-Level Politics, pp. I-6o.

ForD, B., "Worker Housing in the Vermont Copper Belt: Improving Life and Industry Through Paternalism and Resistance", International Journal of Historical Archaeology, I 5:4 (201 I), pp. 725-750.

García Abad, R. and R. Ruzafa Ortega, Mujeres y niños en las minas de Vizcaya (Bilbao, 2010).

GarretT, N. and D. MoretTi, "Artisanal and Small-Scale Mining Governance: The 'Emerging Issue' of 'Unregulated Mining' in Lao PDR", in Lahiri-Dutt (ed.), Between the Plough and the Pick, pp. 3 I I-334.

GIER, J.J., "Mining women find a voice: Working class and environmental feminism in the twenty-first century", in Gier and Mercier (eds), Mining Women, pp. 325-334.

Gier, J.J. and L. Mercier (eds), Mining Women: Gender in the Development of a Global Industry, I670 to the Present (New York, 2006).

Grochain, S., D. Poithily and J.-M. Sourisseau, "From Anticipation to Practice: Social and Economic Management of a Nickel Plant's Establishment in New Caledonia's North Province”, in Filer and Le Meur (eds), Large-Scale Mines and Local-Level Politics, pp. 6 I-97.

Hairong, Y. and B. SAUTMAn, “'The Beginning of a World Empire'? Contesting the Discourse of Chinese Copper Mining in Zambia", Modern China, 39:2 (20I3), Pp. I3 I-I 64 . 
Hall, V.G., Women at Work, I860-1939: How Different Industries Shaped Women's Experiences, (Woodbridge, 2013).

Hammond, J., "Gender, Labour, and Community in a Remote Mining Town", in Arn Keeling and John Sandlos (eds), Mining and Communities in Northern Canada: History, Politics, and Memory (Calgary, 20I5), pp. I I7-I 36.

Harris, R.P., M.M. Redlin and S.E. Tallichet, "What's a Woman to do? Globalized Gender Inequality in Small-Scale Mining”, in Gavin M. Hilson, (ed.), The Socio-Economic Impacts of Artisanal and Small-Scale Mining in Developing Countries (Lisse, 2003), pp. I 89-201. Hemer, S.R., "Gender Mainstreaming and Local Politics: Women, Women's Associations and Mining in Lihir", in Filer and Le Meur (eds), Large-Scale Mines and Local-Level Politics, pp. 29I-3 I 2.

Hemphill, S., "Women in the Mines", Minnesota History, 6r:3 (2008), pp. 92-IOI.

Higgins, K.J., "Licentious Liberty" in a Brazilian Gold-Mining Region: Slavery, Gender, and Social Control in Eighteenth-Century Sabará, Minas Gerais (Pennsylvania, 2007).

Hilson, G., "Small-Scale Mining, Poverty and Economic Development in Sub-Saharan Africa: An overview", Resources Policy, 34 (2009), pp. I-5.

Hofmeester, K., "Economic Institutions and Shifting Labour Relations in the Indian, Brazilian, and South African Diamond Mines", in Karin Hofmeester and Pim de Zwart (eds), Colonialism, Institutional Change and Shifts in Global Labour Relations (Amsterdam, 2018), pp. 67-108.

JANuARIUS, J., "Feeling at Home: Interiors Domesticity, and the Everyday Life of Belgian Limburg Miners in the 1950s", Home Cultures, 6:I (2009), pp. $43-70$.

Januarius, J., "Picturing the Everyday Life of Limburg Miners: Photographs as a Historical Source", International Review of Social History, 53:2 (2008), pp. 293-3 I 2.

Jenkins, K., "Women, Mining and Development: An Emerging Research Agenda”, Extractives Industries and Society, I:2 (2014), pp. 329-339.

Jenkins, K. and G. Rondón, “'Eventually the Mine Will Come': Women Anti-Mining Activists' Everyday Resilience in Opposing Resource Extraction in the Andes", Gender and Development, 23:3 (2015), pp. 4I $5-43$ I.

KalusA, W.T., "Death, Christianity, and African Miners: Contesting Indirect Rule in the Zambian Copperbelt, 1935-1962", The International Journal of African Historical Studies, 44: I (20I I), pp. 89-I I 2.

Kelliher, D., "Solidarity and Sexuality: Lesbians and Gays Support the Miners 1984-5”, History Workshop Journal, 77:I (2014), pp. 240-262.

Kirby, P., “Travail des enfants, risques professionnels et législation industrielle dans les industries textiles et minières en Grande-Bretagne au début du XIX e siècle”, Le Mouvement Social, 249:4 (20I4), pp. 9I-I I4. 
Knotter, A., "Mining", in Hofmeester and Van der Linden (eds), Handbook Global History of Work, pp. 237-258.

Kumar Nite, D., "Familist Movement and Social Mobility: The Indian Colliers (Jharia) I895-1970", Indian Historical Review, 4I:2 (2014), pp. 297-322.

LAhiri-DutT, K. (ed.), Between the Plough and the Pick: Informal, Artisanal and Small-Scale Mining in the Contemporary World (Canberra, 2018).

LAhiri-DutT, K., "'May God Give Us Chaos so that We May Plunder': A Critique of 'Resource Curse' and Conflict Theories", Women in Action, 2 (2006), pp. I 8-28.

Lahiri-DutT, K., "Bodies In/Out of Place: Hegemonic Masculinity and Kamins' Motherhood in Indian Coal Mines", South Asian History and Culture, 4:2 (2013), pp. 21 3-229.

LAHIRI-DuTT, K., “Digging to Survive: Women's Livelihoods in South Asia's Small Mines and Quarries", South Asian Survey, I 5:2 (2008), pp. 2 I 7-244. Lahiri-DutT, K., "Digging Women: Towards a New Agenda for Feminist Critiques of Mining", Gender, Place and Culture: A Journal of Feminist Geography, 19:2 (2012), pp. 193-2 I 2.

LAHIRI-DutT, K., "Gender (Plays) in Tanjung Bara Mining Camp in Eastern Kalimantan, Indonesia”, Gender, Place and Culture: A Journal of Feminist Geography, 20:8 (2013), pp. 979-998.

LAHIRI-DuTT, K., "Mainstreaming Gender in the Mines: Results from an Indonesian Colliery", Development in Practice, I6:2 (2006), pp. 2 I 5-22 I. LAHIRI-DutT, K., "Reframing the Debate on Informal Mining", in Lahiri-Dutt (ed.), Between the Plough and the Pick, pp. I-28.

LAHiri-DutT, K., "Roles and Status of Women in Extractive Industries in India: Making a Place for a Gender-Sensitive Mining Development", Social Change, 37:4 (2007), pp. 37-64.

LAHIRI-DuTT, K. (ed.), Gendering the Field: Towards Sustainable Liveliboods for Mining Communities (Canberra, 20I I).

Lahiri-Dutt, K. and G. Burke, "Gender Mainstreaming in Asian Mining: A Development Perspective", in Lahiri-Dutt (ed.), Gendering the Field, pp. 213-230.

Lahiri-DutT, K. and M. Macintyre (eds), Women Miners in Developing Countries: Pit Women and Others (London, 2006).

Lahiri-Dutt, K. and K. Robinson, "Period' Problems at the Coalface", Feminist Revierw, 89: I (2008), pp. I02-I 2 I.

Laite, J.A., "Historical Perspectives on Industrial Development, Mining, and Prostitution", The Historical Journal, 52:3 (2009), pp. 739-76I.

LAVigne, D., "More than Mines: Industrial Decline, Gender, and the Iron Range's Cluett, Peabody, and Company Arrow Factories, 1946-1979", Minnesota History, 66:2 (2018), pp. 54-65.

LaVigne, D., "Rebel Girls: Women in the Mesabi Iron Range Strike of I916", Minnesota History, 65:3 (2016), pp. 90-100. 
Lawson, L., "Rice, Sapphires and Cattle: Work Lives of Women Artisanal and Small-Scale Miners in Madagascar", in Lahiri-Dutt (ed.), Between the Plough and the Pick, pp. I7 I-192.

Leal, C., "Slave Mining and Emancipation", in Claudia Leal, Landscapes of Freedom: Building a Postemancipation Society in the Rainforests of Western Colombia (Tucson, AR, 20I8), pp. 27-60.

LINDEN, M. VAN DER, "The International Labour Organization, I9I9-20I9: An Appraisal", Labor: Studies in Working-Class History of the Americas, I6:2 (2019), pp. I I-4I.

LynAs, D., "A Good Business or a Risky Business: Health, Safety and Quality of Life for Women Small-Scale Miners in PNG”, in Lahiri-Dutt (ed.), Between the Plough and the Pick, pp. Is I-I 70.

Macintyre, M., "Modernity, Gender and Mining: Experiences from Papua New Guinea", in Lahiri-Dutt (ed.), Gendering the Field, pp. 2 I-32.

Maнy, P., "Sex Work and Livelihoods: Beyond the 'Negative Impacts on Women' in Indonesian Mining", in Lahiri-Dutt (ed.), Gendering the Field, pp. 49-66.

Martini, M. and L. Papastefanaki, "Introduction: Des économies familiales adaptatives en temps de crise dans l'Europe méditerranéenne", The Historical Review/La Revue Historique XV (2018), pp. 9-22.

Mathias, R., "Japan in the Seventeenth Century: Labour Relations and Work Ethics", International Review of Social History, 56:SII9 (20I I), pp. $217-243$.

Mercier, L., "Bordering on Equality: Women Miners in North America", in Lahiri-Dutt (ed.), Gendering the Field, pp. 33-48.

Meyer, A., A.G. Morris and M. Steyn, "Chinese Indentured Labour on the Witwatersrand Mines, South Africa (ad 1904-1910): A Bioarchaeological Analysis of the Skeletal Remains of 36 Chinese Miners", Goodwin Series, I I (20I3), pp. 39-5 I.

Mishra, P.P., "Coal Mining and Rural Livelihoods: Case of the Ib Valley Coalfield, Orissa”, Economic and Political Weekly, 44:44 (2009), pp. I I 7-I 23 .

Moody, R., Rocks E Hard Places: The Globalization of Mining. (London, 2007).

Moretti, D., "The Gender of the Gold: An Ethnographic and Historical Account of Women's Involvement in Artisanal and Small-Scale Mining in Mount Kaindi, Papua New Guinea”, Oceania, 76:2 (2006), pp. I 33-I 49.

Mukhopadhaya, P. and K. Lahiri-Dutt, "Women as Marginal Workers in Informal Mining and Quarrying, India: A Preliminary Analysis”, Journal of the Asia Pacific Economy, I9:2 (2014), pp. 290-309.

Murdock, C.E., "A Gulag in the Erzgebirge? Forced Labor, Political Legitimacy, and Eastern German Uranium Mining in the Early Cold War, I946-I949”, Central European History, 47:4 (2014), pp. 791-82 I. 
NaVarrete, M.C., Génesis y desarrollo de la esclavitud en Colombia, Siglos XVI y XVIII. (Cali, 2005).

O’Mara, R, “Zimbabwe: The Land of King Solomon's Mines”, The Antioch Review, 65:4 (2007), pp. 618-635.

O'Faircheallaigh, C, “Indigenous Women and Mining Agreement Negotiations: Australia and Canada”, in Lahiri-Dutt (ed.), Gendering the Field, pp. 87-109.

Ofosu-Mensah, E.A., "Historical and Modern Artisanal Small-Scale Mining in Akyem Abuakwa, Ghana”, Africa Today, 64:2 (2017), pp. 68-91.

Parmenter, J., "Experiences of Indigenous Women in the Australian Mining Industry", in Lahiri-Dutt (ed.), Gendering the Field, pp. 67-86.

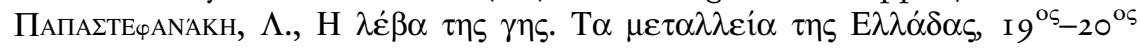
$\alpha i \omega ́ v \alpha \varsigma$ (Athens, 20I7).

Perks, R., "Towards a Post-Conflict Transition: Women and Artisanal Mining in the Democratic Republic of Congo", in Lahiri-Dutt (ed.), Gendering the Field, pp. 177-196.

Perks, R., J. Kelly, S. Constantian and P. Pham, "Resources and Resourcefulness: Gender, Human Rights and Resilience in Artisanal Mining Towns of Eastern Congo", in Lahiri-Dutt (ed.), Between the Plough and the Pick, pp. 209-234.

PiPer, L., "Subterranean Bodies: Mining the Large Lakes of North-West Canada, I 92 I-I 960", Environment and History, I 3:2 (2007), pp. I 55-I 86.

Powell, A.K., "Coal Industry", in Whitley (ed.), From the Ground Up, pp. I 26-I 4 I.

Ramos, D., “Don Minho a Minas”, Revista do Arquivo Público Mineiro, Belo Horizonte, 44: I (2008), pp. I32-I 53.

Reeve, W. P., “Silver Reef and Southwestern Utah's Shifting Frontier”, in Whitley (ed.), From the Ground Up, pp. 250-27I.

Regan, A.J., "Bougainville: Origins of the Conflict, and Debating the Future of Large-Scale Mining", in Filer and Le Meur (eds), Large-Scale Mines and Local-Level Politics, pp. 253-4I4.

Robb, K., M. Moran, V. ThOm and J. Coburn, Indigenous Governance and Mining in Bolivia (Queensland, 2015).

Roels, L., “'In Belgium, Women Do All the Work': The Labour of Women in the Coalmines of Liege, Nineteenth-Early Twentieth Centuries", Revue belge d'bistoire contemporaine/Belgisch Tijdschrift voor Nieurste Geschiedenis, 38: I(2008), pp. 45-86.

Rolston, J.S., “Talk about Technology: Negotiating Gender Difference in Wyoming Coal Mines", Signs: Journal of Women in Culture and Society, 35:4 (2010), pp. 893-918.

Rolston, J.S., Mining Coal and Undermining Gender: Rhythms of Work and Family in the American West (New Brunswick, NJ, 2014). 
Rose, C., "Lonely Men, Loose Women: Rethinking the Demographics of a Multiethnic Mining Camp, Kanaka Flat, Oregon”, Historical Archaeology, 47:3 (2013), pp. 23-35.

SACCHETTI, G., "Le mani, la fronte ... Lavoro e quotidianità nelle miniere di lignite", S-Nodi. Pubblici e Privati nella Storia Contemporanea, Io (20I3), pp. 32-47.

SAMADDAR, R., "Theorising Transit Labour in Informal Mineral Extraction Processes", in Lahiri-Dutt (ed.), Between the Plough and the Pick, pp. I33-I 50.

Sampson, J., Colliers in Corsets? Uncovering Stark County's NineteenthCentury Coal Mining Women, Thinking Gender Papers, UCLA: Center for the Study of Women (Riverside, CA, 20I2).

SANNA, F., "La famille et l'OST: effets divergents de la rationalisation dans l'industrie minière de l'Europe du Sud pendant l'entre-deux-guerres", The Historical Review/La Revue Historique XV (2018), pp. 57-90.

Sarti, R., A. Bellavitis and M. Martini (eds), What is Work? Gender at the Crossroads of Home, Family, and Business from the Early Modern Era to the Present (New York, 20I8).

SAult, N., "Condors, Water, and Mining Heeding Voices from Andean Communities", Ethnobiology Letters, 9: ( (201 8), pp. I 3-29.

Scambary, B., "Mining Agreements, Development, Aspirations, and Livelihoods", in Jon Altman and David Martin (eds), Power, Culture, Economy. Indigenous Australians and Mining (Canberra, 2009), pp. I7I-202.

Schmoll, B., "Masculine and Dead in the Mining Community: The Gendering of Death and the Monongah Mine Explosion of 1907", Journal of Appalachian Studies, I 9: I/2 (2013), pp. 27-45.

Segal, NaOmi, “'War Conducted under Certain Rules, but Nonetheless War': Arbitration, Capital and Labour in the Western Australian Gold Mining Industry, I90I-I 4", Labour History, 93 (2007), pp. I09-I 26.

SIWILA, L.C., "Reconstructing the Distorted Image of Women as Reproductive Labour on the Copperbelt Mines in Zambia (1920-1954)", Journal for the Study of Religion, 30:2 (2017), pp. 75-89.

Spence, J. and C. Stephenson, “'Side by Side with Our Men'? Women's Activism, Community, and Gender in the 1984-1985 British Miners' Strike", International Labor and Working-Class History, 75:I (2009), pp. 68-84.

Sprague, J., "From International to Transnational Mining: The Industry's Shifting Political Economy and the Caribbean”, Caribbean Studies, 43:I (20I 5), pp. 73-I I 2.

Stepenoff, B., “'I'm a Johnny Mitchell Man': Gender and Labor Protest in the Pennsylvania Hard Coal Uprising, I900-1902", in Gier and Mercier (eds), Mining Women, pp. I8 I-I94.

Thomas, E.A., Coal in Our Veins: A Personal Journey (Logan, UT, 2012), pp. 2I-35, 89-97. 
Velasco Murillo, D., "Laboring Above Ground: Indigenous Women in New Spain's Silver Mining District, Zacatecas, Mexico, I620-1770", Hispanic American Historical Review, 93:I (2013), pp. 3-32.

Wagner, D., "Beryllium Mining”, in Whitley (ed.), From the Ground Up, pp. I66-I94.

Walender, A.R., "Engendering Responses to Complex Emergencies: Lessons from South Sudan", Prism, 6: I (2016), pp. I 54-163.

Weinstein, B., “They Don't Even Look like Women Workers': Femininity and Class in Twentieth-Century Latin America", International Labor and Working-Class History, 69 (2006), pp. 161-176.

Whitley, C. (ed.), From the Ground Up: The History of Mining in Utah (Logan, UT, 2006).

Yakovleva, N., "Perspectives on Female Participation in Artisanal and Small-Scale Mining: A Case-Study of Birin North District of Ghana”, Resources Policy, 32 (2007), pp. 29-4I.

Yoshida, K. and R. MrYaUCHI, "Invisible Labor: A Comparative Oral History of Women in Coal Mining Communities of Hokkaido, Japan, and Montana, USA, I890-1940", in Gier and Mercier (eds), Mining Women, pp. I36-I 2 .

Zappia, C.A., "Labor, Race, and Ethnicity in the West Virginia Mines: Matewan” Journal of American Ethnic History, 30:4 (20I I), pp. 44-50. ZimmermanN, S., "Globalizing Gendered Labour Policy: International Labour Standards and the Global South, I919-1947", in Eileen Boris, Dorothea Hoehtker and Susan Zimmermann (eds), Women's ILO: Transnational Networks, Global Labour Standards, and Gender Equity, I919 to Present (Leiden, 20I8), pp. 227-254.

Zimmermann, S., “Equality of Women's Economic Status: A Major Bone of Contention in the International Gender Politics Emerging During the Interwar Period", The International History Review, 41:1 (2019), pp. 200-277. 